\title{
MOGUĆNOSTI I PRETPOSTAVKE \\ FILIGRANOLOŠKIH ISTRAŽIVANJA U KONTEKSTU ISTRAŽIVANJA ZADARSKE GLAGOLJSKE BAŠTINE
}

\author{
RESEARCH POSSIBILITIES AND PREREQUISITES \\ OF WATERMARK RESEARCH IN THE CONTEXT \\ OF RESEARCH OF ZADAR GLAGOLITIC HERITAGE
}

\author{
Marijana Tomić \\ Odjel za informacijske znanosti \\ Centar za istraživanje glagoljaštva \\ Sveučilište u Zadru \\ mtomic@unizd.hr \\ Laura Grzunov \\ Odjel za informacijske znanosti \\ Sveučilište u Zadru \\ lgrzunov@unizd.hr \\ Žana Eškinja \\ bobiczana@yahoo.com
}

UDK / UDC [003.349.1:09:676.026.22]:[02:004.085.7] Izvorni znanstveni rad / Original scientific paper

Primljeno / Received: 31. 8. 2020.

Prihvaćeno / Accepted: 9. 11. 2020.

\section{Sažetak}

Cilj i svrha. Projekt digitalizacije i istraživanja vodenih znakova glagoljskih rukopisa zadarske provenijencije provodi se na Sveučilištu u Zadru u sklopu projekta Digitalizacija, bibliografska obrada i istraživanje tekstova zadarsko-šibenskog područja iz razdoblja do kraja 19. st. pisanih glagoljicom, bosančicom i latinicom. U radu se opisuju pripremna i prva faza projekta čiji je cilj bio istražiti mogućnosti filigranoloških istraživanja u kontekstu istraživanja pisane baštine. Kako bi se stvorili preduvjeti za filigra- 
nološka istraživanja, u sklopu pripremne faze projekta izrađen je protokol digitalizacije vodenih znakova, izrađena je baza podataka vodenih znakova VoZnaZD, a vodeni su znakovi digitalizirani i opisani. Svrha je istraživanja uvidjeti mogućnosti i pretpostavke filigranoloških istraživanja te ulogu strukturiranih baza podataka o vodenim znakovima kao pretpostavke filigranoloških istraživanja.

Pristup. Na temelju pregleda literature iz područja filigranologije postavljen je teorijski okvir, a na temelju sadržajne analize relevantnih međunarodnih baza vodenih znakova izrađen je aplikacijski profil potreban za izradu baze podataka vodenih znakova te protokol digitalizacije. Mogućnosti filigranoloških istraživanja prikazane su kroz studiju slučaja.

Rezultati. Rad je donio pregled stanja istraživanja u području filigranologije u Hrvatskoj te utvrdio potrebu za uporabom skupne online dostupne baze vodenih znakova kao pretpostavke daljnjih sustavnih filigranoloških aktivnosti. Prikazana je baza podataka vodenih znakova VoZnaZD, njezine značajke, mogućnosti i aplikacijski profil za opis vodenih znakova. Studijom slučaja dokazane su mogućnosti filigranoloških istraživanja u kontekstu istraživanja pisane baštine.

Ograničenja. Analizu mogućnosti filigranoloških istraživanja potrebno je učiniti na širem korpusu, za što je potrebna suradnja šire zajednice. Takvo je istraživanje u planu u idućim etapama projekta.

Originalnost/vrijednost. Filigranologija je u Hrvatskoj podzastupljena znanstvena disciplina, a baze vodenih znakova uobičajeno su lokalne i u zatvorenom pristupu, čime se onemogućuju značajnija istraživanja vodenih znakova u Hrvatskoj. Ovim radom potvrđene su mogućnosti filigranoloških istraživanja i važnost baze vodenih znakova te su učinjeni temelji za izradu nacionalnog skupnog kataloga vodenih znakova u otvorenom pristupu.

Ključne riječi: baza podataka vodenih znakova, digitalizacija vodenih znakova, filigranologija, glagoljski rukopisi, vodeni znak

\begin{abstract}
Aim and purpose. The project of digitization and research of watermarks of Glagolitic manuscripts of Zadar provenance has been carried out at the University of Zadar as part of the project Digitization, bibliographic description and research of texts written on Glagolitic, Croatian Cyrillic and Latin scripts until the end of the $19^{\text {th }}$ century in Zadar and Šibenik areas. This paper describes the preliminary and the first stages of the project, the goal of which is to study the possibilities of watermark research in the context of written heritage studies. In order to create the prerequisites for watermark research, within the preliminary project phase, the protocol for watermark digitization was proscribed, a watermark database was created, and the watermarks on paper were digitized and described. The purpose of the research is to identify the possibilities and
\end{abstract}


obstacles of watermark research as well as the role of the structured watermark database in watermark research.

Approach. A theoretical framework was designed on the bases of the literature overview. The content analysis of the relevant international watermark databases was conducted for the purpose of creating an application profile of the watermark database and digitization protocol. The possibilities of watermark research were investigated by a case study method.

Results. The article presents a comprehensive review of the literature on watermark research in Croatia and demonstrates the need for the development of an online watermark database as a prerequisite for further systematic watermark research. The VoZnaZD watermark database and its features are described, as well as it possibilities and application profile for watermark description. The case study proved the possibilities of the watermark research in the context of the written heritage research.

Limitations. A new analysis of the watermark research needs to be done on a larger corpus, which requires the cooperation of the wider community. Such a research is planned in the next stages of the project.

Originality / value. Filigranology is an underrepresented scientific discipline in Croatia, and watermark databases are usually local and in closed access, all of which complicates any significant research on watermarks in Croatia. This paper confirms the possibilities and value of the watermark research and the importance of the watermark database, and lays the foundations for the development of a national union catalog of watermarks in open access.

Keywords: filigranology, Glagolitic manuscripts, watermark, watermark database, watermark digitization

\section{Uvod}

Papir je materijal od kojeg je izrađena većina građe koja se čuva u arhivima i knjižnicama, a njegovo istraživanje pridonosi poznavanju povijesti knjige, pismenosti i kulture uopće. Kao podloga za pisanje pojavljuje se relativno kasno. Izumljen je u Kini godine 105., a u Europi se pojavljuje u 12. stoljeću, i to posredstvom Arapa. Najstariji europski rukopis pisan na papiru arapskog podrijetla, Breviarium et Missale mozarabicum, bio je napisan prije 1036. godine u samostanu Santo Domingo de Silos u Burgosu, a poznato je da je na Siciliji arapski papir bio korišten već 1061. godine. ${ }^{1}$ Pretpostavlja se da se papir u Španjolskoj počeo proizvoditi prije 1150., u Italiji, u Fabrianu, 1283. godine, nakon čega prodire

1 Bull's head and mermaid: the history of paper and watermarks from the Middle Ages to the modern period / edited by Peter Ruckert, Sandra Hodeček, Emanuel Wenger. Stuttgart: Landesarchiv Baden Württemberg; Vienna: Austrian Academy of Sciences, 2009. Str. 12. [citirano 
vrlo brzo u ostatak Europe i polako zamjenjuje pergamenu. Proizvodio se ručno, lijevanjem papirne mase u kalup koji se sastojao od drvenog okvira i mreže koju su činile paralelne okomito postavljene žice. Kada se papirna masa ulila u kalup, nakon procesa sušenja, papir je na mjestima žica prozirniji, odnosno na njemu su vidljive linije. Unutar kalupa nalazio se žicom oblikovan logo proizvođača papira koji je bio učvršćen u središte jedne od polovica sita za papir, koji je također vidljiv kao prozirniji dio papira, a naziva se vodenim znakom ili filigranom. Filigrane su u početku izrađivali proizvođači papira, no vrlo brzo izradu preuzimaju obrtnici, često zlatari. Početkom 16. st. povremeno su bile izrađivane i dodatne oznake koje su bile smještene u drugu polovicu sita, a nazivaju se kontramarke ili kontraoznake. Pretpostavlja se da su dva radnika u 12-satnom radnom vremenu mogli proizvesti do 5000 araka papira, a kalup je trajao otprilike dvije godine. ${ }^{2}$ Bilo je uobičajeno da mlin ima dva kalupa, a onda i dva od žice izrađena znaka koja tvore vodeni znak. Zbog toga, ali i zbog trošenja kalupa tijekom vremena, papir koji je bio proizveden u istom mlinu često može imati dvije ili više varijanti vodenog znaka, koje se nazivaju parovi. Prema broju postojećih varijanti može se pretpostaviti broj kalupa koji je bio u upotrebi u pojedinom mlinu, na temelju čega se pak može pretpostaviti veličina mlina i značajke njegova poslovanja.

Istraživanje vodenih znakova na papiru poduzima se u okvirima pomoćne povijesne znanosti filigranologije, a rezultati tih istraživanja značajno pridonose poznavanju obrazaca proizvodnje rukopisa i stare i rijetke građe općenito, datiranju nedatiranih dokumenata te razumijevanju mnogih društvenih, kulturnih, ekonomskih i drugih značajki života zajednice u kojoj je papir bio korišten, ali i boljem poznavanju trgovačkih putova u Europi. ${ }^{3}$

Istraživanja vodenih znakova uobičajeno rezultiraju katalozima vodenih znakova koji se sastoje od slike vodenog znaka, bilo da je riječ o precrtanom ili o digitaliziranom znaku, te njegova opisa. Takvi katalozi služe kao pomagala za daljnja istraživanja vodenih znakova te rukopisa i knjiga u kojima se vodeni znakovi pronalaze, a preduvjet njihove učinkovitosti jest to da su u otvorenom pristupu te da je njima opisano i datirano čim više vodenih znakova.

Iako se u Hrvatskoj vodeni znakovi uobičajeno istražuju u arhivima i knjižnicama, ${ }^{4}$ katalozi se rade lokalno i nisu javno dostupni, što otežava istraživanja

2020-29-10]. Dostupno na: https://bernstein.oeaw.ac.at/twiki/pub/Main/ProjectExhibitions/bernstein 2009 book en.pdf.

2 Isto, str. 13.

3 Lewincamp, S. Watermarks within the Middle Eastern manuscript collection of the Baillieu Library. // The Australian Library Journal 61, 2(2012), str. 102. DOI: 10.1080/00049670.2012.10722324. 0

4 Najznačajnija istraživanja vodenih znakova u knjižnicama provode se u Nacionalnoj i sveučilišnoj knjižnici u Zagrebu. Više o tome vidjeti u: Štefanac, T. Metode i postupci istraživanja i obrade vodenih znakova na građi iz fonda Nacionalne i sveučilišne knjižnice u Zagrebu. // Arhivi, knjižnice, muzeji: mogućnosti suradnje u okruženju globalne informacijske infrastrukture 23(2020). (u tisku) 
i onemogućuje uvid u podatke o vodenim znakovima na papirima korištenim u knjigama koje se čuvaju u hrvatskim ustanovama.

U sklopu projekta istraživanja vodenih znakova na papiru glagoljskih rukopisa zadarskog područja koji se provodi na Sveučilištu u Zadru nastoje se utvrditi obrasci proizvodnje rukopisa na zadarskom području, ali i cjelokupan kontekst pisane kulture toga područja koji uključuje i nabavu i baratanje papirom i sl. te koristiti podatke o vodenim znakovima kao pomagalo za datiranje nedatiranih rukopisa i u druge istraživačke svrhe.

Budući da u Hrvatskoj ne postoji baza podatka vodenih znakova dostupna online, takva je izrađena u sklopu projekta, s nakanom da tako prikupljeni podaci budu primjereni za provedbu značajnijih filigranoloških istraživanja utemeljenih na međunarodnim principima i suvremenim filigranološkim metodama. Dizajnirajući bazu, posebno se brinulo o izradi aplikacijskog profila za opis vodenih znakova koji jamči interoperabilnost s relevantnim međunarodnim bazama podataka, odnosno kojim se omogućuje to da se podaci mogu neometano isporučivati u međunarodne baze vodenih znakova. Takva načela pridonijela su tome da se s pravom može tvrditi kako su tom bazom ostvareni preduvjeti za izradu standardizirane skupne nacionalne baze vodenih znakova, a primijenjeni aplikacijski profil može se širiti dodatnim elementima opisa, ovisno o potrebama ustanove, korisnika ili pak projekata.

U radu se opisuje prva faza projekta, čiji je cilj bio istražiti mogućnosti filigranoloških istraživanja u kontekstu istraživanja pisane baštine. Kako bi se taj cilj ostvario, u pripremnoj je fazi izrađen protokol digitalizacije vodenih znakova, dizajnirana je i izrađena baza podataka vodenih znakova VoZnaZD te su digitalizirani vodeni znakovi i opisani u navedenoj bazi. Svrha je istraživanja uvidjeti mogućnosti i ograničenja filigranoloških istraživanja provedenih na temelju online-baza vodenih znakova, istražiti opravdanost uporabe baza podataka vodenih znakova koje omogućuju otvoreni pristup podacima o vodenim znakovima, kao i ulogu nalaza filigranoloških istraživanja u boljem razumijevanju pisane baštine.

U radu je posebno predstavljena baza vodenih znakova zadarskih glagoljskih rukopisa VoZnaZD, čija je iskoristivost istražena studijom slučaja.

\section{Filigranologija}

Ivan Balta definira filigranologiju kao ,pomoćnu povijesnu znanost koja obrađuje povijest i pojavu papira te na temelju toga datira starinu papira, odnosno isprave, “5 dok Jakov Stipišić, uz ulogu filigranoloških nalaza u datiranju rukopisa, ističe i njihovu ulogu u utvrđivanju falsifikata, odnosno vjerodostojnosti isprava te usmjerava pozornost na važnost dostupnosti podataka o već opisanim vode-

5 Balta, I. Pregled pomoćnih povijesnih znanosti. Osijek: Matica hrvatska: Grafika, 2000. Str. 73. 
nim znakovima, čime se povećava mogućnost datiranja nedatiranih rukopisa na temelju identifikacije vodenog znaka. ${ }^{6}$ Istraživanja vodenih znakova imaju više različitih ciljeva, od onih čiji je cilj datiranje rukopisa, do onih koji su usmjereni na rekonstrukciju proizvodnje rukopisa i ostale kodikološke aspekte, odnosno bibliografski opis tiskanih knjiga, pa sve do onih koji su usmjereni na opis razvoja motiva korištenih u vodenim znakovima, njihovu simboliku i korespondenciju s umjetničkim pravcima vremena njihova nastanka.

Za sam nastanak filigranologije kao posebne znanstvene discipline vrlo su važna dva posljednja desetljeća 19. i prve godine 20. stoljeća. Jedna od prvih objavljenih zbirki vodenih znakova jest ona koju je godine 1804. objavio Gotthelf Fischer von Waldheim. On je objavio 30 precrtanih vodenih znakova iz 14. stoljeća i zaključio da ,ako netko sakupi oznake rijetkog papira, to ima utjecaj na određivanje razdoblja, uz veliku točnost, dokumenata ili rukopisa koji imaju istu oznaku. “7 Pravim začetnicima uporabe istraživanja vodenih znakova u svim disciplinama koje se bave papirom i knjigom smatraju se Charles Moïse Briquet i Piccard. Briquet godine 1907. u Ženevi objavljuje djelo Filigrani: povijesni rječnik oznaka na papiru od njihove pojave oko 1282. do 1600. u kojem je opisao i precrtao više od 16000 vodenih znakova. ${ }^{8} \mathrm{Uz}$ to, Briquet je prikupljao i ostale podatke o papiranama, koji često potkrepljuju njegova otkrića i koji su mu omogućili određivanje podrijetla papirâ koje je opisivao. Važan je Briquetov prinos to da je uspostavio stručnu terminologiju u području filigranologije te ovjerio metodologiju uporabe vodenih znakova za ubikaciju i datiranje papira. ${ }^{9}$ Godine 1968. tiskano je drugo izdanje toga djela, s velikim dopunama i ispravcima, koje je uredio Allan Stevenson, a ono i u današnje vrijeme predstavlja standard pri datiranju, lokalizaciji i identifikaciji europskog papira, iako su se metode istraživanja od tada značajno izmijenile. ${ }^{10}$ Filigranolozi su od Briqueta naslijedili metode prikupljanja i opisa vodenih znakova, a bibliografi, odnosno knjižničari koji se bave obradom stare i rijetke građe, na temelju tog su djela nastojali izraditi procedure i način opisa vodenih znakova. ${ }^{11}$

\footnotetext{
${ }^{6}$ Stipišić, J. Pomoćne povijesne znanosti u teoriji i praksi: latinska paleografija, opća diplomatika, kronologija. Zagreb: Školska knjiga, 1972. Str. 19.

7 Fischer von Waldheim, G. Beschreibung einiger typographischen Seltenheiten nebst Beyträgen zur Erfindungsgeschichte der Buchdruckerkunst. Nürnberg: Lechner, 1804. Str. 138.

8 Briquet, C. M. Les filigranes: dictionnaire historique des marques du papier des leur apparition vers 1282 jusqu'en 1600. Paris: Picard u. a., 1907.

9 Isto.

10 Briquet, C. M. Les Filigranes, dictionnaire historique des marques du papier dès leur apparition vers 1282 jusqu'en 1600 : a facsimile of the 1907 edition with supplementary material contributed by a number of scholars / edited by Allan Stevenson. Amsterdam: Paper publications Society, 1968. 11 Bidwell, J. The study of paper as evidence, artefact, and commodity. [citirano 2020-04-08]. Dostupno na: https://ilab.org/articles/study-paper-evidence-artefact-and-commodity
} 
Moramo se složiti da je razloge u korist istraživanja papira, a onda i filigranoloških istraživanja koja se provode u sklopu širih istraživanja povijesti knjige najbolje argumentirao J. Bidwell, te ih stoga ovdje sažimamo:

1. detaljno istraživanje vodenih znakova i ostalih tragova proizvodnje na papiru može pridonijeti otkrivanju bibliografskih dokaza koji pomažu datiranju i ubiciranju dokumenata, kao i interpretaciji važnosti navedenih dokumenata, otkrivanju pogrešnih datuma tiska otisnutih na starim knjigama, kao i određivanju pravilne kolacije kod rukopisa koji su tijekom povijesti bili preuvezivani

2. istraživanja papira, na kojem je pisana i otisnuta većina građe koja se čuva u knjižnicama i arhivima, kao i povijesna istraživanja metoda izrade papira te razlika u tim metodama kroz povijest, mogu usporedbom i povezivanjem pridonijeti boljem poznavanju popratnih industrija kao što su trgovina papira, povijest dizajna te drugih kulturnih utjecaja

3. istraživanja papira još su uvijek nedovoljno proučena u kontekstu nakladničke industrije, a upravo bi ta istraživanja mogla znatno pridonijeti boljem poznavanju povijesti nakladništva s obzirom na to da je prodaja papira uključivala ugovore s naručiteljima u kojima su bili precizirani mnogi podaci koji jasno govore o nakladničkim procesima, porastu, odnosno padu nakladničkih pothvata kao i okolnostima u kojima su nakladničke kuće poslovale. ${ }^{12}$

\subsection{Filigranologija u Hrvatskoj}

U Hrvatskoj je istraživanje vodenih znakova vezano uz rad Vladimira Mošina, na čiju je inicijativu osnovan Filigranološki kabinet 1949. godine pri Arhivu Hrvatske akademije znanosti i umjetnosti u Zagrebu..$^{13}$ Zahvaljujući njegovu radu i radu njegovih suradnika, analizom materijala iz domaćih i stranih arhiva prikupljen je veliki broj vodenih znakova, a nakon njihove klasifikacije bili su izrađeni albumi s opisima znakova, njihovoj provenijenciji i vremenskoj upotrebi te se na temelju tih podataka utvrđivala datacija papira. Rezultat tog pionirskog rada predstavlja album Vodeni znakovi XIII. i XIV. vijeka (objavljen 1957. godine u 2. sveska) koji je Mošin napisao sa Seidom M. Traljićem. ${ }^{14}$ Nakon toga, Mošin je nastavio s prikupljanjem i objavljivanjem vodenih znakova, te godine 1954 .

\footnotetext{
12 Isto.

13 Gulin, A.; A. Kolarić; Z. Ladić. Voditelji i ravnatelji Odsjeka za povijesne znanosti Zavoda za povijesne i društvene znanosti Hrvatske akademije znanosti i umjetnosti u Zagrebu (1948.-1998.). // Zbornik Odsjeka za povijesne i društvene znanosti Hrvatske akademije znanosti i umjetnosti, 17(1999), str. 224. [citirano: 2020-11-06]. Dostupno na: https://hrcak.srce.hr/15870.

14 Mošin, V. A.; S. M. Traljić. Vodeni znakovi XIII. i XVI. vijeka. Zagreb: Jugoslavenska akademija znanosti i umjetnosti, 1957.
} 
objavljuje rad Filigranologija kao pomoćna historijska nauka, ${ }^{15} \mathrm{u}$ kojem prikazuje povijest papira od početka do dolaska papira u Europu s naglaskom na mlinovima papira država kao što su Njemačka, Slovenija, Španjolska, Portugal, Francuska, Italija, čak i Sjeverna Amerika itd. Riječ je o radu u kojem Mošin detaljno prikazuje povijest filigranologije, stanje istraživanja i istraživačkih metoda koje se koriste u filigranologiji te se opravdano može tvrditi da je njime Mošin utemeljio filigranologiju kao pomoćnu povijesnu znanost u Hrvatskoj. Godine 1977. radom Filigranološka problematika i papir Dubrovačkog arhiva ${ }^{16}$ Mošin ulazi u specifičnije i dublje istraživanje i kontekstualizaciju vodenih znakova. Za hrvatsku su filigranologiju izuzetno važni i radovi Georga Einedera koji posebno obrađuju papirane i vodene znakove Austro-Ugarske Monarhije. ${ }^{17}$ Njegov se rad povezuje i s radom jednog od najvećih stručnjaka i najplodnijih autora u području filigranologije, E. J. Labarrea, čiji se doprinos prvenstveno ogleda u usustavljivanju terminologije i definiranju pojmova vezanih uz papir i njegovu proizvodnju. U svom je enciklopedijskom rječniku Labarre usustavio tehničku terminologiju vezanu uz papir i vodene znakove na engleskom, francuskom, njemačkom, danskom, talijanskom, španjolskom i švedskom jeziku, a taj je rad neizostavan u svakom sustavnom istraživanju papira i papirana.$^{18} \mathrm{O}$ samoj proizvodnji papira u Hrvatskoj Mošin je pisao tek djelomično, ${ }^{19}$ no značajnije se time bavila Miroslava Despot, ${ }^{20}$ ekonomska povjesničarka, a osobito u novije vrijeme Tatjana Puškadija Ribkin koja detaljno opisuje i povijest papirane zagrebačkog Stolnog kaptola i vodene znakove na papiru proizvedenom u njoj, kao i kakvoću različitih papira koji su iz te papirane tijekom njezina djelovanja izlazili. ${ }^{21}$

Poglavlje o filigranologiji zastupljeno je i u kapitalnom djelu Pomoćne povijesne znanosti u teoriji i praksi Jakova Stipišića, ${ }^{22}$ kao i u pregledu pomoćnih povijesnih znanosti Ivana Balte, ${ }^{23}$ te možemo s pravom reći da je u teorijskom smislu riječ o disciplini koja je u Hrvatskoj zastupljena, iako, nažalost, ne postoji

15 Mošin, V. Filigranologija kao pomoćna historijska nauka. // Zbornik odsjeka za povijesne znanosti Zavoda za povijesne i društvene znanosti Hrvatske akademije znanosti i umjetnosti 1(1954), str. 25-93.

16 Mošin, V. Filigranološka problematika i papir Dubrovačkog arhiva // Historijski zbornik 2930(1976-1977), str. 51-59.

17 Eineder, G. The ancient paper-mills of the former Austro-Hungarian Empire and their watermarks. Hilversum: Paper Publications Society, 1960.

18 Labarre, E. J. Dictionary and encyclopaedia of paper and paper-making. London: Oxford University Press, 1952.

19 Mošin, V. Filigranologija kao pomoćna. Nav. dj., str. 54.

20 Despot, M. Pokušaji manufakture u građanskoj Hrvatskoj u 18. stoljeću. Zagreb: JAZU, 1962. Str. 75-81.

21 Puškadija-Ribkin, T. Vodeni znakovi papirane zagrebačkoga Stolnog kaptola. // Arhivski vjesnik 37(1994), str. 209-220.

22 Stipišić, J. Nav. dj., str. 19-26.

23 Balta, I. Nav. dj., str. 73. 
standardizirani nacionalni protokol izrade dokumentacije o vodenim znakovima, usustavljena i općeprihvaćena terminologija niti postoje baze vodenih znakova $u$ otvorenom pristupu kakve su u današnje vrijeme neizostavan dio filigranoloških istraživanja.

\section{Katalozi vodenih znakova - digitalizacija, opis i online dostupnost vodenih znakova}

Međunarodni se katalozi vodenih znakova u današnje vrijeme objavljuju kao online-baze podataka u otvorenom pristupu, čime se ostvaraju preduvjeti za sustavnija filigranološka istraživanja. Tako je i Briquetovo kapitalno djelo Le Filigrane u današnje vrijeme dostupno online, kao skenirani dokument ${ }^{24}$ te kao baza podataka $B O$ - Briquet Online. ${ }^{25}$ Zbirka vodenih znakova koje je tiskom objavio Piccard ${ }^{26}$ također je objavljena kao online-baza podataka Piccard online, ${ }^{27}$ a obuhvaća sve vodene znakove koje je Piccard objavio u tiskanom izdanju, ali i one koje je precrtao i obradio, ali su ostali neobjavljeni. Uz bazu podataka dostupno je i kazalo. U projekt je uključena Njemačka zaklada za znanost, a baza se pretražuje primarno na temelju ikona koje predstavljaju motive vodenih znakova pa je moguće pretraživanje baze bez poznavanja terminologije motiva. Uz to, moguće je pretraživanje baze i pomoću teksta, a u sklopu projekta u sustav je ugrađen višejezični tezaurus motiva na temelju kojega se može pretraživati na engleskom, francuskom i njemačkom jeziku.

Pretraživanje motiva u bazama podataka uobičajeno predstavlja poseban izazov te je u sklopu EU Bernstein The Memory of Paper projekta ${ }^{28}$ izrađen iscrpan tezaurus motiva vodenih znakova koji je objavljen na devet jezika (engleski, njemački, francuski, grčki, talijanski, ruski, španjolski, portugalski i mađarski). ${ }^{29} \mathrm{Te}-$ zaurus se redovito ažurira i dodaju mu se novi jezici, a u posljednjoj je verziji 10.3 objavljen u travnju 2017. ${ }^{30} \mathrm{U}$ sklopu projekta Pisana baština tezaurus je preveden na hrvatski jezik.

\footnotetext{
24 Briquet, C. M. Nav. dj. [citirano: 2020-11-06]. Dostupno na: https://doc.rero.ch/record/23217/ files/ob_447_1.pdf

25 BO - Briquet Online. [citirano: 2020-11-06]. Dostupno na: http://briquet-online.at/

26 Piccard, G. Die Wasserzeichenkartei Piccard im Hauptstaatsarchiv Stuttgart. Stuttgart: W. Kohlhammer, 1961-1997.

27 Piccard online. [citirano: 2020-04-08]. Dostupno na: https://www.piccard-online.de/start.php.

28 Bernstein: the memory of paper. [citirano: 2020-11-06]. Dostupno na: https://memoryofpaper. eu/BernsteinPortal/appl_start.disp

29 Frauenknecht, E.; C. Kämmerer; P. Rückert; M. Stieglecker. Watermark - terms: vocabulary for watermark description. [citirano: 2020-11-06]. Dostupno na: https://www.memoryofpaper.eu/ products/watermark_terms_v11.1_en.pdf

30 Frauenknecht, E.; C. Kämmerer; P. Rückert; M. Stieglecker. Nav. dj.
} 
Popis relevantnih dostupnih baza podataka, materijala i alata potrebnih za opis $\mathrm{i}$ istraživanje vodenih znakova, kao i bibliografiju radova, održava i objavljuje na svojim stranicama projekt Bernstein: The Memory of Paper. ${ }^{31}$

Digitalizacija vodenih znakova u današnje je vrijeme uobičajen dio svih istraživanja vodenih znakova, kao i njihove evidencije i opisa te gotovo u potpunosti zamjenjuje precrtavanje vodenih znakova koje je bilo uobičajeno prije digitalizacije. Istraživanje vodenih znakova često se provodi istodobno s digitalizacijom cijelog kodeksa, osobito iz razloga što istraživanja vodenih znakova nadopunjuju znanja o kodeksu koja se dobivaju kodikološkim, paleografskim, povijesnoumjetničkim i drugim istraživanjima, koja se također danas odvijaju uz pomoć digitalnih tehnologija. Interdisciplinarni pristup istraživanjima kodeksa, odnosno rukopisne i stare knjige pridonio je i uporabi srodnih tehničkih metoda digitalizacije. Tako je, nakon što se polako napušta nekad prevladavajuća metoda precrtavanja vodenih znakova, počela uporaba digitalizacije kamerom uz pomoć konzervatorski sigurnih svjetlećih folija koje se umeću ispod papira kako bi se vodeni znak osvijetlio i na taj način snimio te digitalizacija neinvazivnim konzervatorskim tehnikama multispektralnog sustava snimanja koji se inače koristi u kodikologiji pri digitalizaciji rukopisa, jer omogućuje, za razliku od snimanja kodeksa pod običnim bijelim svjetlom, uočavanje posebnih detalja na snimljenim objektima kao što su pismo i korišteni alati za pisanje, način liniranja, tekst pisan ispod gornjeg teksta (kod palimpsesta), uopće čitanje tekstova koji su oštećeni, izuzetno slabo ili nikako vidljivi pod bijelim svjetlom zbog oštećenja i sl. Mogućnosti automatskog opisa vodenih znakova, njihove katalogizacije i identifikacije još se uvijek istražuju, a najčešće idu u smjeru uporabe biometrijskih metoda u digitalizaciji i automatizaciji prepoznavanja digitaliziranog sadržaja.

Opis vodenog znaka izrađuje se na način koji omogućuje okupljanje, a onda i pretraživanje vodenih znakova prema motivima te razlikovanje vodenih znakova $\mathrm{s}$ istim ili sličnim motivom. Razlikovna su obilježja širina i visina vodenog znaka, širina i gustoća linija i kontramarka (kontraoznaka). Bilježenje gustoće i udaljenosti linija omogućuje uočavanje vodenih znakova koji potječu iz istog mlina, no kod kojih su uočena odstupanja zbog trošenja kalupa tijekom upotrebe.

U Hrvatskoj još uvijek ne postoji nacionalni protokol digitalizacije ni smjernice za ujednačeni opis vodenih znakova, kao ni mrežno dostupan skupni katalog vodenih znakova, a lokalni podaci nisu u otvorenom pristupu. Bilježenje podataka o vodenim znakovima samo u lokalnim bazama čini te podatke nedostupnima $\mathrm{i}$ zatvorenima, a time i skrivenima istraživačima, a nedostatak skupne baze podataka onemogućuje mnoga istraživanja, datiranja nedatiranih rukopisa, ujedinjavanja fragmenata, ali i mnoga druga istraživanja rukopisa i starih knjiga. Ta je činjenica potaknula izgradnju baze vodenih znakova zadarskih glagoljskih rukopisa.

31 Bernstein: The Memory of Paper. Links. [citirano: 2020-11-06]. Dostupno na: https://memoryofpaper.eu/BernsteinPortal/appl_start.disp 


\section{Projekt Digitalizacija, bibliografska obrada i istraživanje tekstova zadarsko-šibenskog područja iz razdoblja do kraja 19. st. pisanih gla- goljicom, bosančicom i latinicom}

Na Odjelu za informacijske znanosti Sveučilišta u Zadru u suradnji s Vestigia Institutom za istraživanje rukopisa Sveučilišta u Grazu, u Austriji od 2016. godine provodi se projekt Digitalizacija, bibliografska obrada i istraživanje tekstova zadarsko-šibenskog područja iz razdoblja do kraja 19. st. pisanih glagoljicom, bosančicom i latinicom (dalje Pisana baština). ${ }^{32}$ Od 2020. godine projekt se dalje razvija i u okviru znanstveno-istraživačkog Centra za istraživanje glagoljaštva pri Sveučilištu u Zadru. Projekt je do 2019. bio usmjeren na digitalizaciju i istraživanja zbirke glagoljskih rukopisa koju je prikupio msng. dr. sc. Pavao Kero, a čuva se u Arhivu Zadarske nadbiskupije. Jedan je od rezultata projekta portal Pisana baština ${ }^{33}$ na kojem su objavljeni katalog rukopisa ${ }^{34}$ i katalog vodenih znakova ${ }^{35}$ glagoljskih rukopisa. Portal je izrađen u informacijskom sustavu Indigo, ${ }^{36}$ u kojem se razvijaju, nadograđuju i integriraju oba navedena kataloga. ${ }^{37}$

\subsection{Projekt Izrada kataloga vodenih znakova rukopisa zadarskog područja od 13. do 19. st.}

U skladu s razgranatošću i velikim brojem znanstvenih disciplina čiji su predmet istraživanja rukopisi, projekt Pisana baština koji se provodi podijeljen je u nekoliko istraživačkih skupina, od kojih je jedna usmjerena na istraživanje vodenih znakova na papiru rukopisa zbirke glagoljskih rukopisa Zadarske nadbiskupije. Stoga se unutar projekta provodi manji projekt Izrada kataloga vodenih znakova rukopisa zadarskog područja od 13. do 19. st., ${ }^{38}$ u sklopu kojega se digitaliziraju i

32 Projekt je financiralo Ministarstvo kulture Republike Hrvatske, Sveučilište u Zadru i Vestigia Insitut za istraživanje rukopisa Sveučilišta u Grazu u Austriji. Više o projektu u: Renhart, E.; M. Tomić. Digitalizacija, bibliografska obrada, istraživanje i komuniciranje zadarske pisane baštine. // Arhivi, knjižnice, muzeji: mogućnosti suradnje u okruženju globalne informacijske infrastrukture 20(2017), 222-267.

33 Portal Pisana baština. [citirano: 2020-11-06]. Dostupno na: https://pisanabastina.unizd.hr/

34 Portal Pisana baština. Katalog rukopisa. [citirano: 2020-11-06]. Dostupno na: https://pisanabastina.unizd.hr/?kr=1\&view= grid\&page $=1$

35 Portal Pisana baština. Katalog vodenih znakova. [citirano: 2020-11-06]. Dostupno na: https:// pisanabastina.unizd.hr/?kvz=1\&view= grid\&page $=1$

36 Indigo: hybrid repository platform based on semantic technologies. [citirano: 2020-11-06]. Dostupno na: http://www.eindigo.net/

37 Nakon prelaska projekta pod okrilje Centra za istraživanje glagoljaštva, baze podataka vodenih znakova i rukopisa te tezaurus vodenih znakova nalaze se na portalu Glagolab: portal i digitalni laboratorij za suradnička istraživanja i promicanje hrvatskoga glagoljaštva. [citirano: 2020-11-06]. Dostupno na: https://glagolab.unizd.hr/

38 Projekt je financirala Zaklada Hrvatske akademije znanosti i umjetnosti godine 2018. te Vestigia Insitut za istraživanje rukopisa Sveučilišta u Grazu u Austriji. 
istražuju vodeni znakovi glagoljskih rukopisa te se izrađuje katalog u skladu sa suvremenim međunarodnim uzusima digitalizacije i opisa, čime se stvorila podloga za filigranološka istraživanja kojima se nadopunjuju kodikološka, paleografska, povijesna i druga istraživanja glagoljskih rukopisa.

U sklopu projekta nastavlja se rad koji je na istraživanjima vodenih znakova koji su pronađeni na papirima rukopisa zadarskog područja započeo V. Mošina. On je opisao vodene znakove koje je pronašao u zadarskom Notarskom arhivu (Državni arhiv u Zadru), a koji datiraju iz 13. i 14. stoljeća. Dodatno je pregledao građu 13. i 14. stoljeća u samostanskim arhivima, no ondje nije pronašao vodene znakove. Ovim se projektom nastoji nadograđivati Mošinov rad, i to filigranološkim istraživanjima papira na kojima su pisani glagoljski rukopisi zadarskog područja, s ciljem upotpunjavanja korpusa vodenih znakova zadarskog područja te oblikovanja baze podataka vodenih znakova, a sve u svrhu boljeg poznavanja glagoljske baštine zadarskog područja. Ovaj projekt ima dvojaku ulogu. S jedne strane istražuje mogućnosti filigranoloških istraživanja i ulogu nalaza tih istraživanja u upotpunjavanju spoznaja o glagoljskoj baštini te s druge strane gradi strukturiranu online-bazu vodenih znakova i ostvaruje pretpostavke za stvaranje nacionalne skupne baze vodenih znakova.

S obzirom na to da je utvrđeno kako je preduvjet za filigranološka istraživanja baza podataka o vodenim znakovima, a da takva nije postojala u Hrvatskoj, pripremna je faza projekta uključila izgradnju takve baze. Izgradnja baze sastojala se od izrade nacrta baze podataka i aplikacijskog profila i izgradnje baze podataka te usuglašavanja terminologije potrebne za opis motiva vodenih znakova. Osim toga, u toj je fazi bilo potrebno izraditi protokol za digitalizaciju vodenih znakova, digitalizirati ih i u bazu podataka unijeti digitalne reprodukcije i metapodatke. Nakon tih pripremnih radnji, temeljni dio prve faze projekta bio je istražiti mogućnosti filigranologije $u$ istraživanjima glagoljske pisane baštine.

Digitalizacija vodenih znakova provodila se uz pomoć mobilnog konzervatorskog stalka za digitalizaciju stare i rijetke građe Traveller TCCS 4232 i kamere Canon EOS 70D(W) DS126411 ${ }^{39}$ (slika 1) te Slim light - Leuchtfolien Set A4 svjetleće folije za snimanje vodenih znakova na papiru (slika 2).

39 Konzervatorski stalak za digitalizaciju stare i rijetke građe Traveller TCCS 4232 proizveo je i donirao Odjelu za informacijske znanosti Sveučilišta u Zadru Vestigia institut za istraživanje rukopisa Sveučilišta u Grazu. 


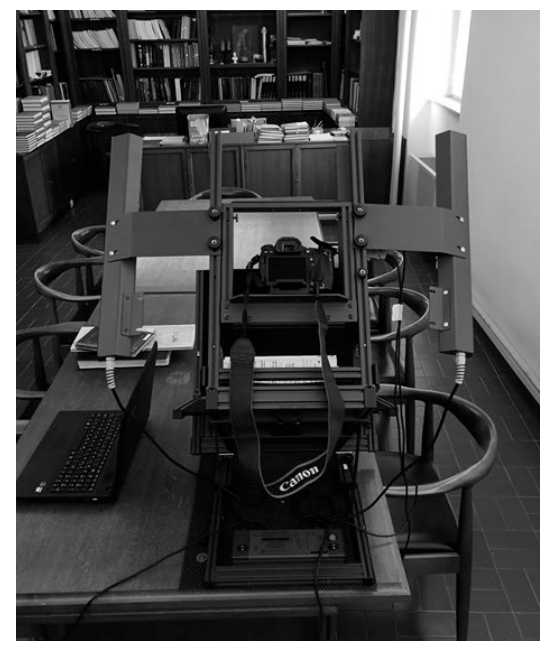

Slika 1. Traveller TCCS 4232 i kamera Canon EOS 70D(W) DS126411

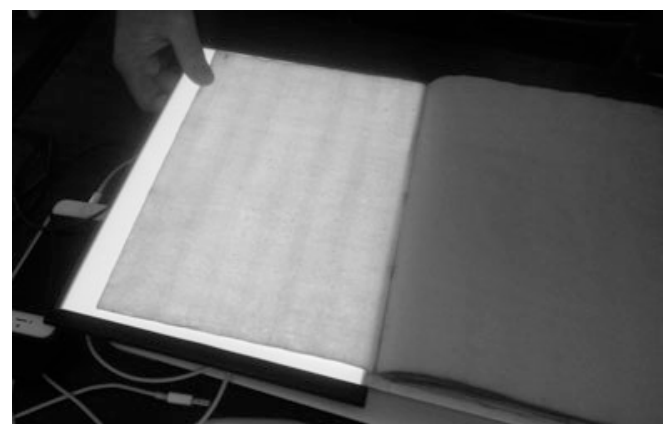

Slika 2. Slimlight folija za snimanje vodenih znakova na papiru

Prema protokolu digitalizacije izrađenom u sklopu projekta, opisu vodenog znaka dodaju se tri slike, i to (1) digitalna reprodukcija vodenog znaka, (2) digitalna reprodukcija vodenog znaka s apliciranim mjerama znaka i linija te (3) grafički prikaz strukture kodeksa s označenim pozicijama vodenog znaka.

Nakon što je vodeni znak digitaliziran, digitalna reprodukcija naknadno je obrađena u programu Adobe Photoshop, u kojem se originalnoj fotografiji dodaje tamniji efekt i smanjuje svjetlina kako bi se vodeni znak i linije bolje uočile. Na slici 3 prikazana je digitalna reprodukcija na kojoj je vidljiv motiv te okomite i vodoravne linije na papiru.

Na slici 4 prikazan je digitalizirani vodeni znak s apliciranim mjerama. Mjere, prema uvriježenim standardima kakvi se primjenjuju u međunarodnim bazama podataka uključuju širinu i visinu vodenog znaka, udaljenost između okomitih linija na papiru te gustoću vodoravnih linija unutar $3 \mathrm{~cm}$. Mjere su preuzete s originalnog rukopisa, s vodenog znaka koji se u rukopisu najbolje raspoznaje, uz pomoć tzv. Slimlight svjetleće folije. Aplicirane mjere preduvjet su daljnjim istraživanjima vodenih znakova te osobito njihove usporedbe s drugim sličnim vodenim znakovima. 


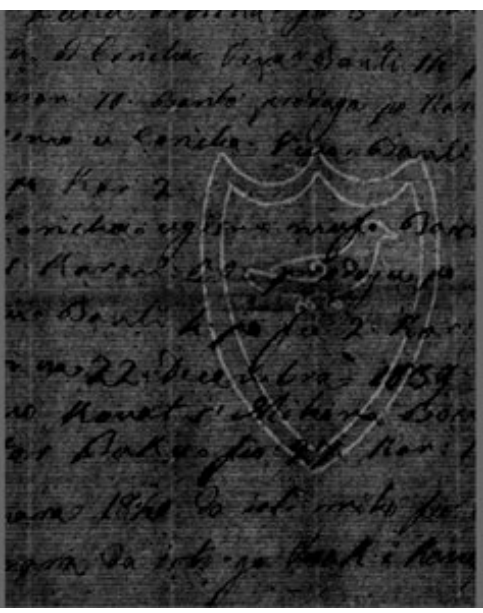

Slika 3. Digitalizirani vodeni znak Ptica u štitu ${ }^{40}$

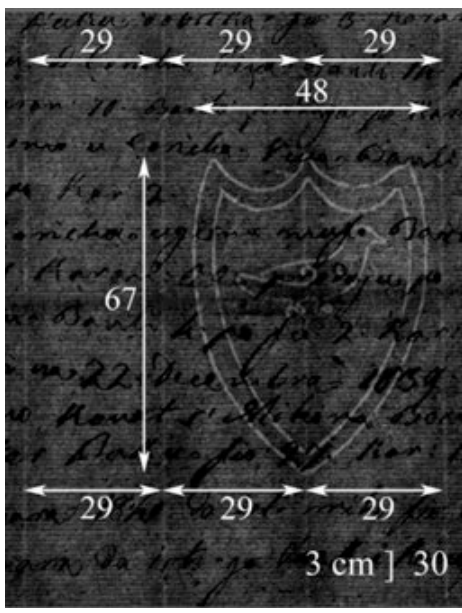

Slika 4. Digitalizirani vodeni znak Ptica $u$ štitu s mjerama ${ }^{41}$

Uz svaku je digitalnu reprodukciju vodenog znaka dodana i kodikološka shema, odnosno grafički prikaz kodeksa na kojem su vidljivi svežnjići, folije i položaj vodenog znaka. Na slici 5 grafički je prikazana struktura kodeksa, i to broj svežnjića od kojih je sačinjen knjižni blok, broj folija unutar svežnjića te raspored i broj vodenih znakova koji se nalaze u rukopisu. Vodeni znakovi označeni su slovima (A, B, C, D, $\mathrm{E}, . .$.$) , a stranica s koje je određeni vodeni znak preuzet za digitalizaciju i istraživa-$ nje posebno je istaknuta bojom. Tako izrađena struktura kodeksa s označenim pozicijama vodenih znakova omogućuje uvid u način izrade kodeksa, odnosno dodatnim se istraživanjima može utvrditi je li dolazilo do paralelne uporabe različitih vrsta papira ili je pak papir bio naknadno dodavan tijekom pisanja. Dodatnim paleografskim, kodikološkim i drugim istraživanjima mogu se utvrditi i razdoblja umetanja dodatnih papira, a usporedbom s drugim kodeksima i dodatne veze među pisarima i sl. Dodatno, ispod grafičkog prikaza strukture kodeksa, struktura je iskazana i uvriježenom kodikološkom formulom. ${ }^{42} \mathrm{Na}$ slici 5 prikazana je struktura kodeksa Kopija iz Libra kvaterna u kojem se nalazi vodeni znak Ptica u štitu.

40 Portal Pisana baština. Katalog vodenih znakova VoZnaZD. Vodeni znak Ptica u štitu. [citirano: 2020-11-06]. Dostupno na: https://pisanabastina.unizd.hr/?kvZ=i\&id=13182

41 Portal Pisana baština. Katalog vodenih znakova VoZnaZD. Vodeni znak Ptica u štitu. [citirano: 2020-11-06]. Dostupno na: https://pisanabastina.unizd.hr/?kvz=iiif.v.a\&id=13182\&tify $=\{\% 22$ pages $\% 22:[2], \% 22$ view $\% 22: \% 22$ info $\% 22\}$

42 O načinu iskazivanja kodikološke strukture vidjeti u: Tomić, M. Katalogizacija starih rukopisa uporabom Pravilnika za opis i pristup građi u arhivima, knjižnicama i muzejima na primjeru zbirke glagoljskih kodeksa Arhiva Zadarske nadbiskupije. // Arhivi, knjižnice, muzeji: mogućnosti suradnje u okruženju globalne informacijske infrastrukture 21(2018), str. 218. 


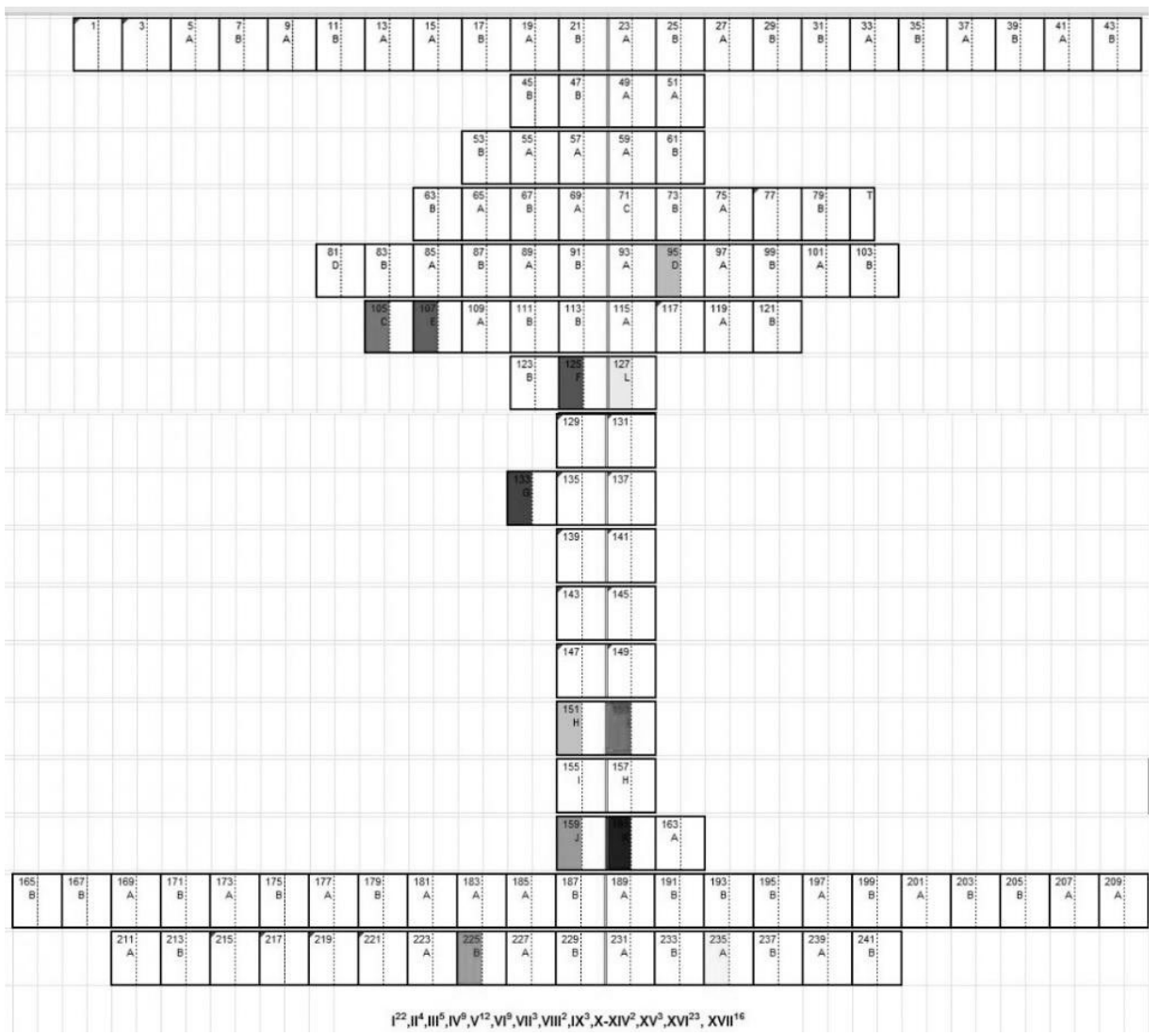

Slika 5. Struktura kodeksa Kopija iz Libra kvaterna s rasporedom i brojem vodenih znakova ${ }^{43}$

Grafički prikaz cijelog kodeksa služi i za daljnja kodikološka istraživanja, a prikaz položaja vodenih znakova i kodeksa može poslužiti kao pouzdan izvor za istraživanja obrazaca proizvodnje kodeksa, razdoblja proizvodnje i nadogradnje kodeksa, itd.

Baza vodenih znakova VoZnaZD izrađena je na način da omogućuje pohranu navedenih digitalnih reprodukcija vodenog znaka te pripadajućih metapodataka za koje je bilo potrebno izraditi aplikacijski profil. Izrada aplikacijskog profila uključivala je istraživanje relevantnih međunarodnih baza vodenih znakova i njihovih elemenata opisa i izrada nacrta modela integracije kataloga vodenih znakova s

43 Portal Pisana baština. Katalog vodenih znakova VoZnaZD. Vodeni znak Ptica u štitu. Prikaz strukture kodeksa. [citirano: 2020-11-06]. Dostupno na: https://pisanabastina.unizd. $\mathrm{hr} /$ ?kvZ=iiif.v.a\&id=13182\&tify $=\{\% 22$ pages $\% 22:[3], \% 22$ panX\%22:0.636,\%22panY\%22:0.522 ,\%22view\%22:\%22info\%22,\%22zoom \%22:0.712\} 
katalogom rukopisa. Na tim je temeljima aplikacijski profil baze vodenih znakova sastavljen od elemenata opisa potrebnih za opis vodenog znaka s naznakom elemenata za koje se predlaže uporaba termina iz kontroliranog rječnika te modela integracije baza vodenih znakova i rukopisa (Prilog 1). Zahtjevi su bili postavljeni tvrci ArhivPRO d.o.o. ${ }^{44}$ koja je izvođač portala Pisana baština izrađenog u okviru Indigo platforme za izgradnju suradničkog sustava za pohranu digitalne kulturne baštine. ${ }^{45} \mathrm{Na}$ portalu Pisana baština već je bio izrađen katalog glagoljskih rukopisa u kojem su rukopisi opisani uz uporabu strojnočitljivog formata UNIMARC, a usklađeno s odredbama Pravilnika za opis i pristup građi u arhivima, knjižnicama i muzejima. ${ }^{46}$ Izgradnja obaju baza podataka unutar istog informacijskog sustava omogućila je integraciju, a onda kroz povezivanje i kontekstualizaciju podataka povećala istraživački potencijal obiju baza. Baza vodenih znakova izrađena u sklopu projekta nazvana je VoZnaZD - Vodeni znakovi zadarskog područja.

Aplikacijski profil za opis vodenog znaka čine sljedeći elementi opisa: naziv, motivi, opis motiva, udaljenost okomitih linija, širina i visina, gustoća vodoravnih linija, Briquetov broj i tvornica papira. Nakon toga slijede oni elementi opisa koji su $\mathrm{u}$ zapis za vodeni znak ugrađeni iz bibliografskog opisa kodeksa u kojem je vodeni znak sadržan, i to: naslov, raspon godina kodeksa, mjesto proizvodnje kodeksa, imatelj kodeksa, signatura kodeksa, ustanova/projekt digitalizacije te napomena. U bazi vodenih znakova VoZnaZD, podaci o kodeksu u kojem je vodeni znak sadržan ugrađuju se izravno iz bibliografskog opisa rukopisa koji se nalaze u katalogu glagoljskih rukopisa izrađenom unutar istog informacijskog sustava Indigo (slika 6). Tako je u sklopu informacijskog sustava Indigo uspješno izrađen alat za istraživanje rukopisa i vodenih znakova koji se temelji na povezivanju podataka iz obiju baza.

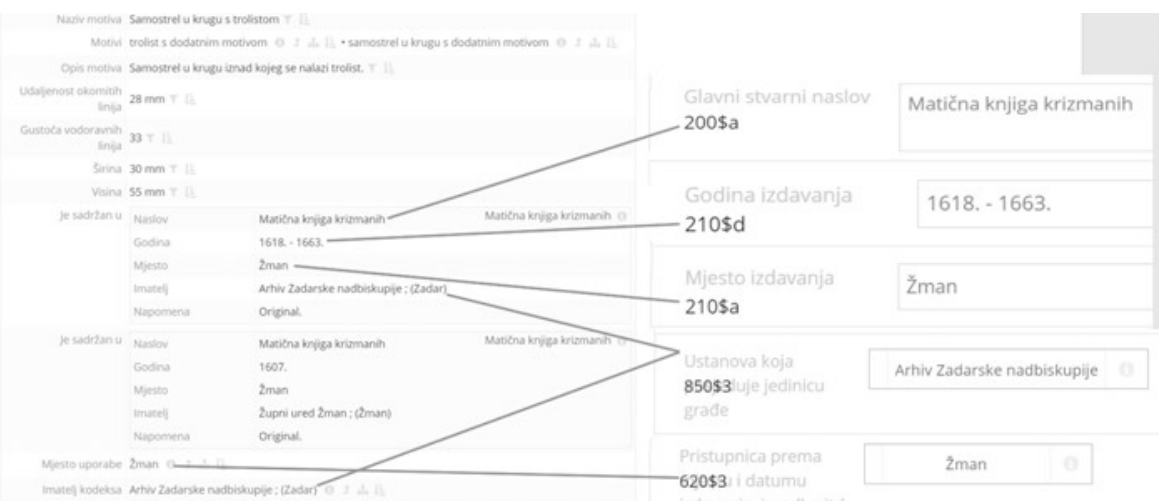

Slika 6. Prikaz integracije kataloga vodenog znaka i kataloga rukopisa

\footnotetext{
${ }^{44}$ ArhivPRO d.o.o. [citirano: 2020-11-06]. Dostuno na: http://www.arhivpro.hr/

45 Indigo. Nav. dj.

46 Usp. Tomić, M. Nav. dj., str. 189-231.
} 


\subsection{Terminologija opisa motiva}

Budući da pri opisu vodenih znakova glavnu teškoću predstavlja prepoznavanje i imenovanje motiva, odnosno terminologija, u prvoj fazi projekta preveden je tezaurus motiva Bernstein Watermark Terms. ${ }^{47}$ Konzorcij EU-projekta Bernstein osmislio je jedinstvenu terminologiju za opis vodenih znakova, koja je prevedena na devet jezika (engleski, njemački, francuski, grčki, talijanski, ruski, španjolski, portugalski i mađarski).

Radna grupa za istraživanje vodenih znakova u sklopu projekta Pisana baština prevela je navedeni tezaurus na hrvatski jezik s ciljem uspostavljanja kontroliranog rječnika i organizacije odnosa među konceptima. Prevedeno je ukupno 965 termina koji su grupirani u 13 kategorija. Vodeni znakovi klasificiraju se prema njihovom motivu u hijerarhijski organiziranim kategorijama koje su prikazane ikonama i riječima. U sklopu informacijskog sustava Indigo izrađena je platforma Tezaurus. $h r$ čija je nakana ponuditi platformu za izradu i okupljanje kontroliranih rječnika u Hrvatskoj, te je bila korištena u sklopu projekta Pisana baština za izradu tezaurusa motiva vodenih znakova (slika 7).
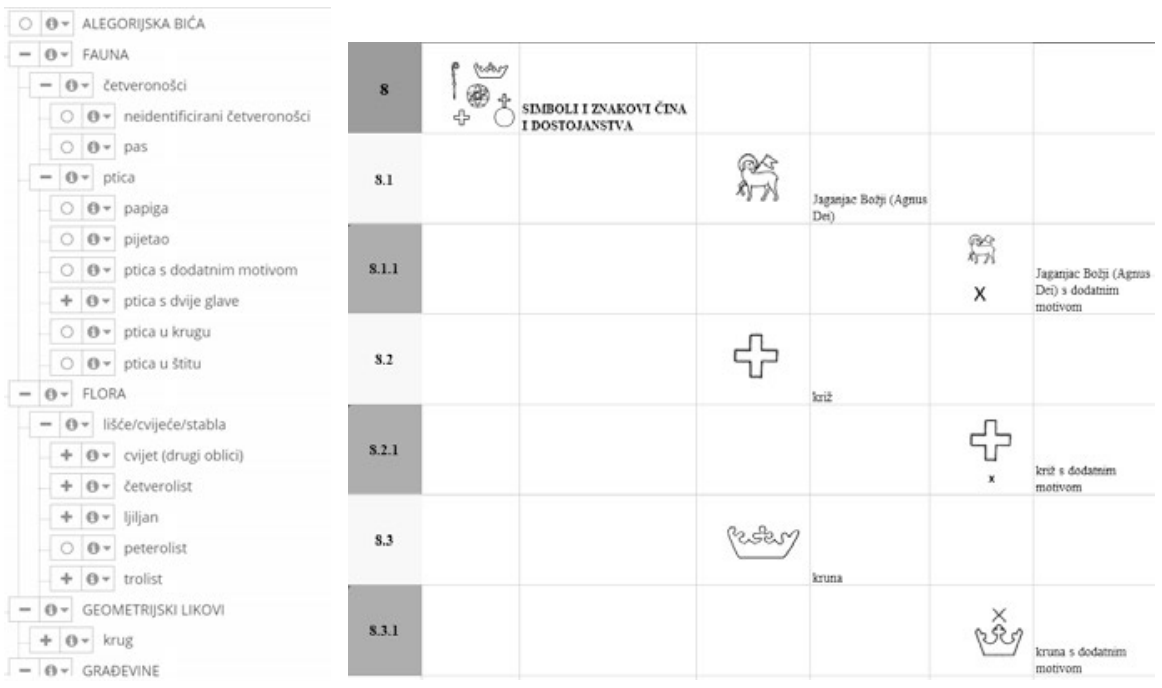

Slika 7. Hijerarhijski organizirane kategorije prema kojima se klasificiraju motivi na projektu Pisana baština

Motivi, uključujući nazive kategorija i potkategorija motiva, zastupljeni su u tezaurusu opisom riječima, ali i slikovnim ikonama koje su uvriježene na međunarodnoj razini. Pojmovi su u tezaurusu opisani hijerarhijskim vezama prema širim i užim kategorijama, a uneseni na hrvatskom i na engleskom jeziku, što bazu čini pretraživom na hrvatskom i na engleskom jeziku te prema ikonama.

47 Frauenknecht, E.; Kämmerer, C.; Rückert, P.; Stieglecker, M. Nav. dj. 


\section{Studija slučaja - vodeni znakovi na papiru rukopisa iz mjesta Žman, Dugi otok}

Nakon što je na temelju Popisa glagoljskih kodeksa Zadarske nadbiskupije ${ }^{48}$ utvrđeno da dio glagoljskih kodeksa koji se čuvaju u Arhivu Zadarske nadbiskupije, a koji predstavljaju važan istraživački korpus u sklopu projekta Pisana baština, nije datiran, na temelju teorijskih spoznaja o mogućnostima filigranoloških istraživanja pri dataciji rukopisa, postavljena je hipoteza da opis i usporedba vodenih znakova u datiranim i nedatiranim rukopisima može pridonijeti dataciji onih $\mathrm{s}$ nepoznatom ili nepouzdanom datacijom. Naime, nedatirani se rukopisi mogu datirati identifikacijom vodenog znaka tako da se isti, za koji je već utvrđena papirana i razdoblje njezina djelovanja, pronađe ako postoji u kojoj od dostupnih baza podataka. Drugi je način da se približna datacija nedatiranog rukopisa postavi na temelju identifikacije vodenog znaka kakav je identificiran i na papiru kojeg od datiranih rukopisa, posebno ako je riječ o rukopisu koji je napisan na istom geografskom području. Tada možemo pretpostaviti da je riječ o rukopisu koji je napisan približno u istom razdoblju kao i onaj koji je datiran, a sadrži isti vodeni znak. $\mathrm{Na}$ takvim temeljima utvrdili smo važnost filigranoloških istraživanja na glagoljskim rukopisima zadarskog područja, i to u svrhu datiranja nedatiranih glagoljskih rukopisa. Dodatno, pregledom literature utvrđeno je da analiza vodenih znakova može pridonijeti saznanjima o načinu proizvodnje rukopisa, kao i vezama među glagoljašima, načinima na koji su nabavljali papir, posuđivali ga među sobom i sl. Ovom studijom slučaja nastojat će se djelomično prikazati mogućnosti filigranoloških istraživanja u kontekstu širih istraživanja pisane baštine.

U sklopu ove studije slučaja obuhvaćeni su glagoljski rukopisi koji se čuvaju u Arhivu Zadarske nadbiskupije, a potječu iz mjestâ Žman, Kali i Sali. Mjesto Kali nalazi se na otoku Ugljanu, a mjesta Žman i Sali na Dugom otoku. Oba su otoka dio Zadarske nadbiskupije, na čijem je području glagoljaška tradicija snažno prisutna kroz natpise na kamenu, kao i zapise na papiru, zbog čega Marija Pantelić i utvrđuje da je zadarsko područje jedan od rasadnika glagoljaštva. ${ }^{49} \mathrm{U}$ zbirci glagoljskih rukopisa, koja se čuva u Arhivu Zadarske nadbiskupije, glagoljske je rukopise okupio i sustavno popisivao i opisivao mnsg. Pavao Kero, istraživač, veliki poznavatelj i poticatelj istraživanja zadarskog glagoljaštva. ${ }^{50}$ Ovim istraživanjem nastojalo se na zaokruženom korpusu rukopisa iz triju mjesta, odnosno dvaju otoka, utvrditi postoje li opravdani razlozi za upotrebu filigranoloških istraživanja pri analizi glagoljske pisane baštine zadarskog područja.

\footnotetext{
48 Kero, P. Popis glagoljskih kodeksa Zadarske nadbiskupije. 2. izd. Zadar: Stalna izložba crkvene umjetnosti, Sveučilište u Zadru, 2015.

49 Pantelić, M. Glagoljski kodeksi Bartola Krbavca. // Hrvastko glagoljsko srednjovjekovlje / Marija Agnezija Pantelić; priredili Petar Bašić, Roman Turčinović. Zagreb: Kršćanska sadašnjost, 2013. Str. 235.

50 Kero, P. Nav. dj.
} 
Pregledano je ukupno 16 rukopisa koji su prethodno bili digitalizirani i opisani u katalogu rukopisa. Rukopisima su pri digitalizaciji bili dodijeljene oznake, u skladu s protokolom digitalizacije opisanom u dokumentu Principles of work and guidelines, Version 3.0. ${ }^{51} \mathrm{U}$ ovom istraživanju preuzete su te unaprijed dodijeljene oznake rukopisa.

Popis rukopisa s pripadajućim oznakama prikazan je u tablici 1.

Tablica 1. Popis rukopisa s pripadajućim oznakama

\begin{tabular}{|l|c|}
\hline Žman_74.1 & Matična knjiga krštenih 1607. - 1610. \\
\hline Žman_74.2 & Matična knjiga krštenih 1607. - 1613. \\
\hline Žman_74.3 & Matična knjiga krštenih 1613. - 1649. \\
\hline Žman_74.4 & Matična knjiga krštenih 1652. - 1668. \\
\hline Žman_74.6 & Matična knjiga vjenčanih 1607. - 1613. \\
\hline Žman_74.7 & Matična knjiga vjenčanih 1607. - 1610. \\
\hline Žman_74.8 & Matična knjiga vjenčanih 1651. - 1668. \\
\hline Žman_74.9 & Matična knjiga vjenčanih 1668. - 1799. \\
\hline Žman_74.10 & Matična knjiga umrlih 1607. - 1612. \\
\hline Žman_74.11 & Matična knjiga umrlih 1612. - 1650. \\
\hline Žman_74.12 & Matična knjiga umrlih 1650. - 1668. \\
\hline Žman_74.14 & Matična knjiga krizmanih 1607. \\
\hline Žman_74.15 & Matica krizmanih 1618. - 1663. \\
\hline Žman_74.16 & Knjiga Stanje duša 1670. - 1694. \\
\hline Žman_74.17 & Knjiga godova \\
\hline Žman_74.18 & Madrikula Bratovštine Svetoga Sakramenta 1753. - 1862. \\
\hline
\end{tabular}

Svi su rukopisi temeljito pregledani te je u njima bilo identificirano, digitalizirano i opisano ukupno 30 vodenih znakova (slika 8). U skladu s protokolom, svaki je vodeni znak u katalogu opisan i opremljen trima slikama, i to digitalnom reprodukcijom vodenog znaka, digitalnom reprodukcijom s apliciranim mjerama te grafičkim prikazom strukture kodeksa.

51 Renhart, E.; M. Tomić. Principles of Work and Guidelines. Version 3.0. [citirano: 2020-07-12]. Dostupno na: https://pisanabastina.unizd.hr/?pr=i\&id=12682 


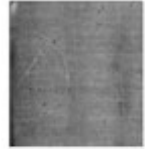

Jamesix Bos

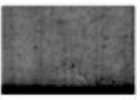

sumeatiel

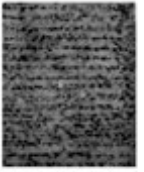

Sovalis

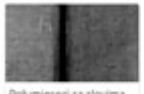

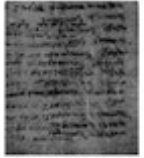
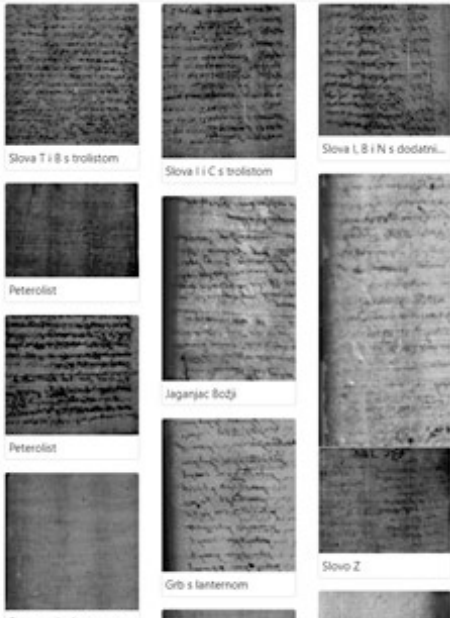

Cestanteriom

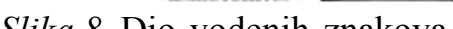

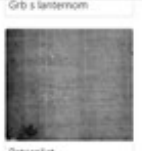

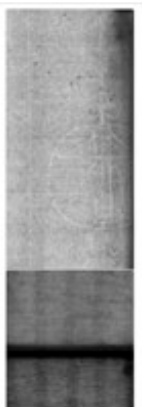

was motertoe
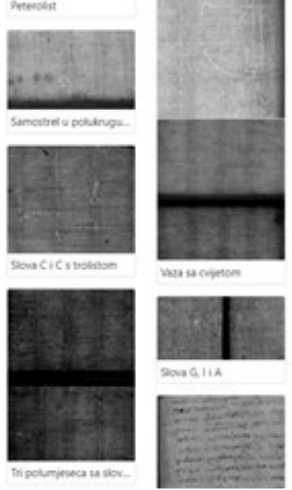
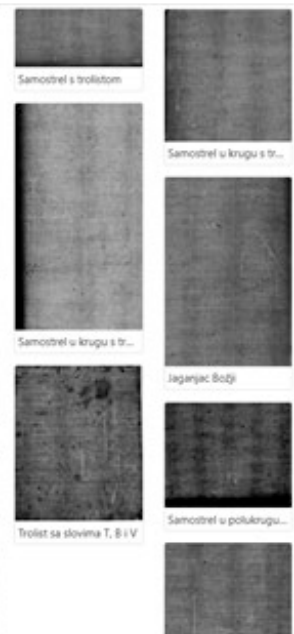

Slika 8. Dio vodenih znakova pronađenih u žmanskim rukopisima prikazanih u katalogu VoZnaZD ${ }^{52}$

Za opis motiva vodenih znakova bio je korišten kontrolirani rječnik, odnosno termini iz prethodno prevedenog tezaurusa vodenih znakova. Time je omogućeno okupljanje svih vodenih znakova s istim motivom koji su uneseni u katalog (slika 9).

Dijelovi motiva

\begin{tabular}{|c|c|c|c|c|}
\hline Pretrabi $1(0)$ & & $\leftarrow 1 / 1 / \rightarrow$ & & \\
\hline \begin{tabular}{|l|l|} 
i & I IU \\
\end{tabular} & 14 & 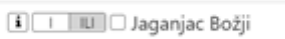 & 3 & (i) $1 /$ if $O$ Ornament \\
\hline 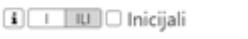 & 9 & (i) I I Iu $\square$ Agnus Dei & 3 & \begin{tabular}{ll|l|l|l|l|} 
& $I$ & Slovo $Z$
\end{tabular} \\
\hline (i) $\quad$ I I IU $\square$ Samostrel & 7 & 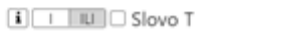 & 3 & \begin{tabular}{ll|l}
$\mathbf{i}$ & $\mathrm{I}$ & $\mathrm{IU}$ \\
\end{tabular} \\
\hline \begin{tabular}{|l|l|l|l|l|l} 
Krug &
\end{tabular} & 6 & i I I I $\square$ Slovo I & 3 & \begin{tabular}{ll|l|l|} 
i & I & Slovo $G$
\end{tabular} \\
\hline 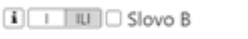 & 5 & (i) $\quad$ I $\mid$ U $\square$ Tri polumjeseca & 2 & (i) 1 I Iu $\bigcirc$ Polumjesec \\
\hline (i) 1 I IU $\square$ Peterolist & 4 & 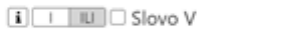 & 2 & i \begin{tabular}{l|l} 
I & IU \\
\end{tabular} \\
\hline \begin{tabular}{|l|l|} 
i & I
\end{tabular} Kontramarka & 4 & \begin{tabular}{ll|l|l|} 
& I
\end{tabular} & 2 & (i) 1 I liu $\bigcirc$ Vaza \\
\hline (i) \begin{tabular}{l|l|l|} 
& Polukrug
\end{tabular} & 4 & (i) 1 II $\square$ Slowo $\mathrm{C}$ & 2 & \begin{tabular}{ll|l|l|l|l|} 
i & Slovo $N$
\end{tabular} \\
\hline
\end{tabular}

Slika 9. Motivi vodenih znakova iz žmanskih rukopisa u katalogu VoZnaZD (portal Pisana baština)

U tablici 2 prikazani su podaci o vodenim znakovima pronađenim na papirima odabranih glagoljskih rukopisa iz mjesta Žman. Podaci su preuzeti iz baze podataka vodenih znakova VoZnaZD i vizualizirani na način da je vidljivo je li i u kojim

52 PortalPisanabaština.KatalogvodenihznakovaVoZnaZD.Vodeniznakoviizžmanskihrukopisa.[citirano: 2020-11-06]. Dostupno na: https://pisanabastina.unizd.hr/?kvz=1\&mr\%5B10037\%5D=o\&fc\%5B10001\%5D \%5Bo10037\%5D=mr\%5B10037\%5D\%3Do\&view=grid\&page=1 . 
rukopisima bio korišten isti vodeni znak, odnosno isti papir. Svaka boja označava po jedan vodeni znak. U slučajevima kada je na vodenom znaku prikazan isti motiv, ali znak ipak nije identičan jer se razlikuje u mjerama ili kojim drugim značajkama, tada se oni tretiraju kao različiti znakovi te su u tablici prikazani različitim bojama. Dodatnim se istraživanjima naknadno utvrđuje je li riječ o istom ili pak o različitim proizvođačima papira. Takav je primjer vidljiv kod znaka samostrel u krugu s dodatnim motivom, gdje su trima bojama prikazane tri varijante znaka $\mathrm{s}$ istim motivom.

U tablicama 2 i 3 prikazane su dvije vrste vizualizacija podataka o vodenim znakovima i pripadajućim rukopisima koje služe za analize podataka.

Tablica 2. Vodeni znakovi u rukopisima iz mjesta Žman

\begin{tabular}{|c|c|c|c|c|c|c|c|c|c|c|c|c|c|c|c|c|c|}
\hline & \multicolumn{17}{|c|}{ VODENI ZNAKOVI } \\
\hline $\begin{array}{l}\text { OZNAKA U } \\
\text { SKLOPU } \\
\text { PROJEKTA }\end{array}$ & \begin{tabular}{|l} 
samostrel \\
u krugu s \\
dodatnim \\
motivom
\end{tabular} & peterolist & $\begin{array}{c}\text { Jaganjac } \\
\text { Božji s } \\
\text { dodatnim } \\
\text { motivom } \\
\end{array}$ & $\begin{array}{c}\text { TBV s } \\
\text { dodatnim } \\
\text { motivom }\end{array}$ & \begin{tabular}{|c|} 
gro s \\
dodatni \\
$\mathrm{m}$ \\
$\mathrm{m}$ \\
motivo \\
$\mathrm{m}$ \\
\end{tabular} & \begin{tabular}{|c|} 
IBN. \\
dodatni \\
$m$ \\
$m$ \\
motivo \\
$m$ \\
\end{tabular} & \begin{tabular}{|c|} 
IC s \\
dodatnim \\
motivom
\end{tabular} & |ornament & $\begin{array}{c}\text { CCs } \\
\text { dodatnim } \\
\text { motivom }\end{array}$ & z & \begin{tabular}{|c|} 
tri \\
mjeseca s \\
dodatnim \\
motivom \\
\end{tabular} & \begin{tabular}{|c|}
$\mathrm{Ls}$ \\
dodatni \\
$\mathrm{m}$ \\
$\mathrm{m}$ \\
motivo \\
$\mathrm{m}$ \\
\end{tabular} & GiA & $\begin{array}{c}\text { vaza s } \\
\text { dodatrim } \\
\text { motivom }\end{array}$ & $\begin{array}{l}\text { crijet } \\
\text { (drugi } \\
\text { oblici) }\end{array}$ & \begin{tabular}{|c|} 
IB s \\
dodatni \\
$\mathrm{m}$ \\
motivom \\
\end{tabular} & $\begin{array}{c}\text { neidentificiani } \\
\text { vodeni znak }\end{array}$ \\
\hline \multicolumn{18}{|l|}{$\underline{Z} \operatorname{man} 74.1$} \\
\hline \multicolumn{18}{|l|}{$\underline{Z} \check{z}_{\operatorname{man}} 74.2$} \\
\hline \multicolumn{18}{|l|}{$\underline{Z} \operatorname{man} 74.3$} \\
\hline \multicolumn{18}{|l|}{$\underline{Z} \operatorname{man} 74.4$} \\
\hline \multicolumn{18}{|l|}{$\underline{Z} \check{\operatorname{man}}_{7} 74.6$} \\
\hline \multicolumn{18}{|l|}{$\underline{\operatorname{man}} .74 .7$} \\
\hline \multicolumn{18}{|l|}{$\underline{Z}$ Żañ 74.8} \\
\hline \multicolumn{18}{|l|}{$\underline{Z} \operatorname{man} 74.9$} \\
\hline \multicolumn{18}{|l|}{$\underline{Z} \check{Z}_{\operatorname{man}} 74.10$} \\
\hline \multicolumn{18}{|l|}{$\underline{Z} \operatorname{man} .74 .11$} \\
\hline \multicolumn{18}{|l|}{$\underline{Z} \check{Z}_{\operatorname{man}}$. 74.12} \\
\hline \multicolumn{18}{|l|}{$\underline{Z} \check{Z} \operatorname{man} .74 .14$} \\
\hline \multicolumn{18}{|l|}{$\underline{Z} \operatorname{man} \_74.15$} \\
\hline \multicolumn{18}{|l|}{$\underline{Z} \underline{Z}_{\operatorname{man}} 74.16$} \\
\hline \multicolumn{18}{|l|}{$\underline{Z}$ man 74.17} \\
\hline$\underline{Z} \operatorname{man} 74.18$ & & & & & & & & & & & & & & & & & \\
\hline
\end{tabular}

Tablica 3. Grupirani podaci o vodenim znakovima i rukopisima koji ih sadržavaju

\begin{tabular}{|c|c|c|c|}
\hline \multirow{2}{*}{$\begin{array}{l}Z \operatorname{man}-74.1 \\
Z \operatorname{man} 74.7\end{array}$} & \multirow{2}{*}{$\begin{array}{l}\text { - Matiēna knjiga krstenih } 1607,-1610 \\
\text { - Matiéna knjiga vjencanih } 1607,-1610\end{array}$} & Žman_74.16 & - $\quad$ Knjiga Stanje duša 1670.-1694. \\
\hline & & Žman_74.16 & - $\quad$ Knjiga Stanje duša 1670.-1694. \\
\hline \multirow{2}{*}{$\begin{array}{l}\sum \operatorname{man}-74.2 \\
2 \operatorname{man}-74.10 \\
2 \operatorname{man}-74.14\end{array}$} & \multirow{2}{*}{$\begin{array}{l}\text { - Matična knjiga krstenih 1607.-1613. } \\
\text { - Matična knjiga umrlih 1607.-1612. } \\
\text { Maticna knjiga krizmanih 1607. }\end{array}$} & Žman 74.16 & - $\quad$ Knjiga Stanje duša $1670 .-1694$. \\
\hline & & Žman_74.16 & - $\quad$ Knjiga Stanje duša $1670 .-1694$. \\
\hline \multirow{3}{*}{$\begin{array}{l}\sum \operatorname{man} \_74.3 \\
\sum \operatorname{man} \_74.11 \\
\sum \operatorname{man}-74.15\end{array}$} & \multirow{3}{*}{$\begin{array}{l}\text { - Matična knjiga krstenih 1613.-1649. } \\
\text { - } \quad \text { Maticna knjiga umrlih 1612-1650 } \\
\text { Mrizmanih 1618.-1663. }\end{array}$} & Žman_74.10 & Matična knjiga umrlih 1607.-1612. \\
\hline & & Žman 74.16 & Knjiga Stanje duša 1670.-1694. \\
\hline & & Žman_74.17 & Knjiga godova \\
\hline$\sum \operatorname{man}-74.3$ & \multirow{2}{*}{$\begin{array}{l}\text { - } \quad \text { Matična knjiga krstenih 1613.-1649. } \\
\text { - } \quad \text { Matica knjiga umrlih 1612.-1650 } \\
\end{array}$} & Žman_74.18 & $\begin{array}{l}\text { - Madrikula Bratovštine Svetoga Sakramenta } \\
1753 .-1862 \text {. }\end{array}$ \\
\hline $2 \operatorname{man} 74.15$ & & Žman 74.17 & Knjiga godova \\
\hline \multirow{2}{*}{$\begin{array}{l}\sum \operatorname{man} \_74.4 \\
\sum \operatorname{man}-74.8 \\
\sum \operatorname{man}-74.12\end{array}$} & \multirow{2}{*}{ 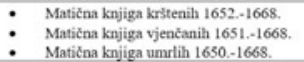 } & Žman_74.6 & Matična knjiga vjenčanih 1607.-1613. \\
\hline & & Žman_74.9 & Matična knjiga vjenčanih 1668.-1799. \\
\hline $2 \operatorname{man} \_74.4$ & - Matična knjiga krstenih 1652-1668. & Žman_74.9 & - $\quad$ Matična knjiga vjenčanih 1668.-1799. \\
\hline $\begin{array}{l}\sum \operatorname{man} \_74.8 \\
\sum \operatorname{man}\end{array}$ & $\begin{array}{l}\text { - Matiéna knjiga vjenćanih 1651,-1668. } \\
\text { - Matiéna knjiga umrlih 1650.-1668. }\end{array}$ & Žman_74.18 & $\begin{array}{l}\text { - Madrikula Bratovštine Svetoga Sakramenta } \\
1753 .-1862 \text {. }\end{array}$ \\
\hline
\end{tabular}


Iz tablica možemo uočiti da je u 16 obrađenih rukopisa pronađeno ukupno 17 motiva, odnosno 30 vodenih znakova.

Vizualizacija podataka pokazuje da je u pet rukopisa (Žman_74.1, 74.2, 74.6, 74.7 i 74.14) bila korištena samo po jedna vrta papira u cijelom rukopisu, u deset rukopisa bile su korištene po dvije vrste papira (Žman_74.3, 74.4, 74.8, 74.9, 74.10, 74.11, 74.12, 74.15, 74.17 i 74.18), a u jednom (Žman_74.16) je bilo korišteno pet različitih vrsta papira.

Od pet rukopisa u kojima je bila korištena po jedna vrsta, četiri (Žman_74.1, 74.2, 74.7, 74.14) imaju vodeni znak samostrel u krugu s dodatnim motivom. Uvidom u podatke o rukopisima, vidljivo je da je riječ je o matičnim knjigama krštenih i vjenčanih koje su pisane u istom razdoblju, od 1607. do 1613. godine. Rukopis (Žman_74.10) koji je iz istog razdoblja također ima papir s istim vodenim znakom, no dodana mu je još jedna vrsta papira, i to Slova $C$ i $C$ s trolistom. Uvidom u strukturu kodeksa (slika 10), koja je grafičkim prikazom dodana u katalogu, vidljivo je da je druga vrsta papira dodana u drugom dijelu rukopisa:

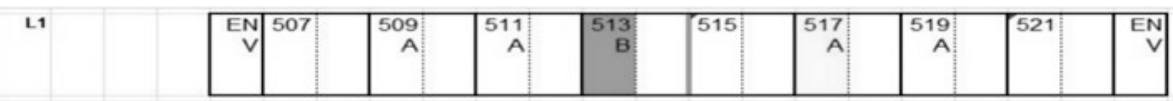

Slika 10. Struktura rukopisa Matična knjiga umrlih, Žman, 1607. - 1612. (Žman_74.10)

Uvidom u digitalnu reprodukciju rukopisa Matična knjiga umrlih, Žman, 1607. - 1612. u katalogu rukopisa, vidljivo je da je novi papir umetnut naknadno, nakon teksta same matične knjige, kao prazne dodatne stranice (slika 11). Dodatnim istraživanjem glagoljskih rukopisa iz mjesta Žman, koje je bilo provedeno u sklopu projekta Pisana baština, utvrđeno je da je riječ o rukopisu koji je bio posljednji u nizu 13 matičnih knjiga koje je Austrijska uprava za Dalmaciju uvezala zajedno dodavši upravo na toj matičnoj knjizi bilješku „Visto e consistente in pagine N.ro 522. Zara li 26 9bre 1827. Dall’ I. Reg(i)o Capitanato Circolare" uz potpis i austrijski grb na crvenom pečatnom vosku. ${ }^{53}$

53 Više o privezivanju, sudbini i kataložnom opisu tih rukopisa vidjeti u: Tomić, M; M. Willer. Glagoljski rukopisi kao privez i umjetna zbirka: primjena Pravilnika za opis i pristup građi u knjižnicama, arhivima i muzejima. // Arhivi, knjižnice, muzeji: mogućnosti suradnje u okruženju globalne informacijske infrastrukture, 23(2020). (u tisku) 


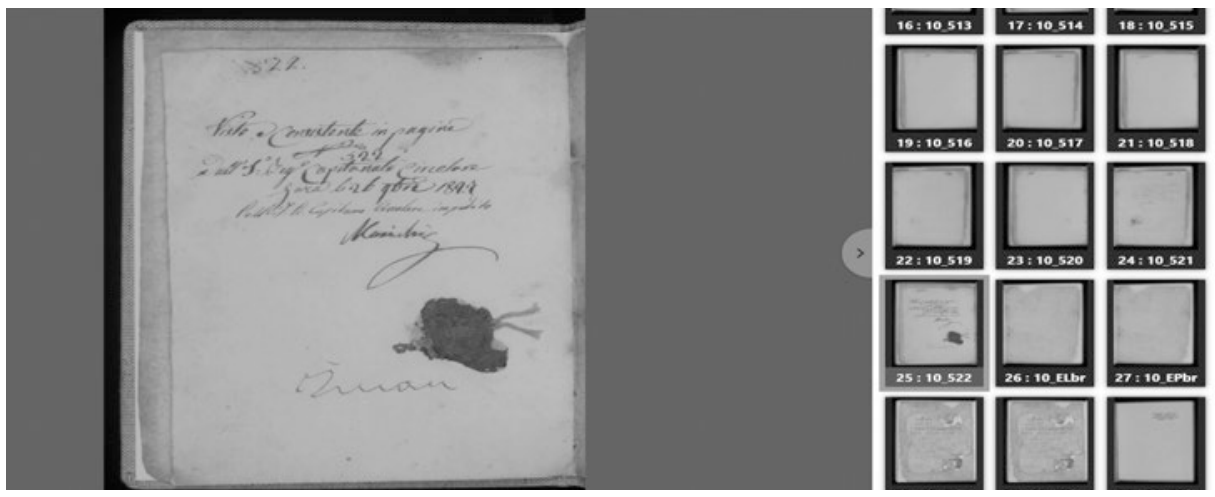

Slika 11. Prikaz digitalne reprodukcije rukopisa u kojoj je od str. 517 umetnut novi papir

Dakle, može se opravdano zaključiti da je pri uvezivanju 13 matica u posljednjoj bio dodan novi papir, koji je onda bio iskorišten i za podatke i pečat kojima su privezane matice bile ovjerene od strane Austrijske uprave za Dalmaciju.

Isti motiv, samostrel u krugu s dodatnim motivom, pronađen je u još trima rukopisima, (Žman_74.3, 74.11 i 74.15), koji su proizvedeni kasnije, odnosno između 1612. i 1663. No vodeni znak koji se pojavljuje u toj grupi rukopisa nije identičan s onim koji se pojavljuje u ranijim rukopisima, a razlika je u mjerama (slike 12 i 13), što može upućivati na to da je riječ o istom proizvođaču, ali kasnije nabavljenom papiru. Iako će se to tek utvrditi dodatnim istraživanjima, s priličnom pouzdanošću možemo pretpostaviti da je papir bio kontinuirano nabavljan od istog proizvođača. U tim je kasnijim rukopisima dodan još jedan papir, s motivom peterolist, što može upućivati na promjenu i dodavanje papira drugog proizvođača, a dodatna paleografska i kodikološka istraživanja koja se provode idu u smjeru da ponude odgovor na pitanje kada je do promjene došlo. 


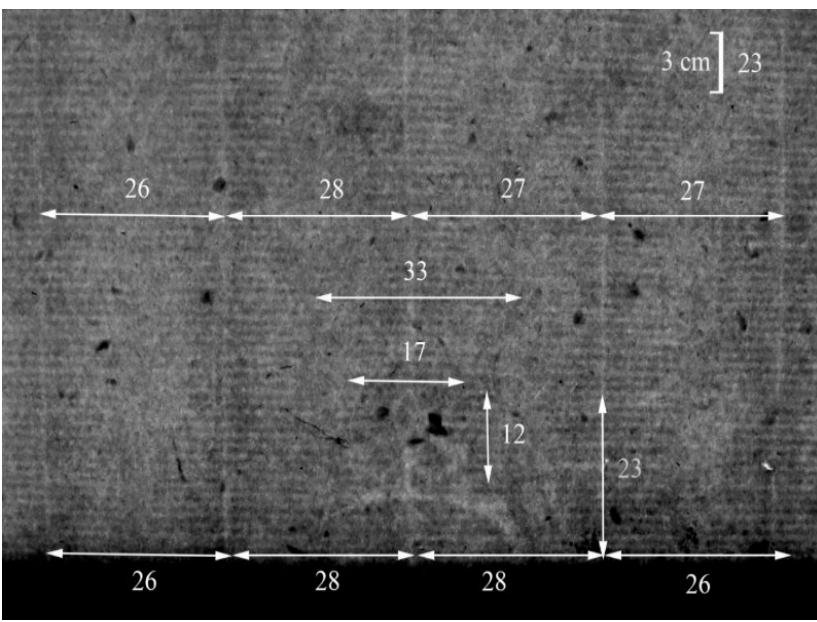

Slika 12. Vodeni znak Samostrel u krugu s dodatnim motivom - rukopis 74.1

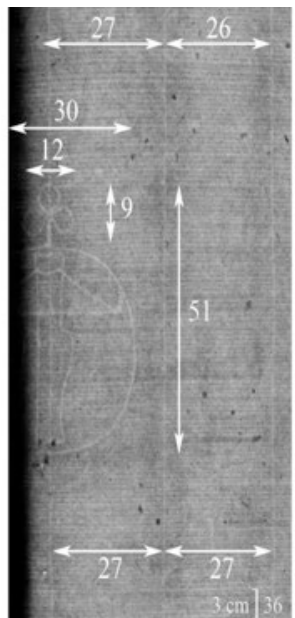

Slika 13. Vodeni znak Samostrel u krugu s dodatnim motivom - rukopis 74.3

Daljnjom je analizom utvrđeno da se kasnijih godina vodeni znakovi u žmanskim rukopisima mijenjaju. Primjerice, u rukopisima 74.4, 74.8 i 74.12 nailazimo na dva ista vodena znaka, Jaganjac Božji s dodatnim motivom i slova TBV s dodatnim motivom. Sva tri rukopisa nastala su u istom razdoblju, između 1650. i 1668. godine. S obzirom na jednak broj vodenih znakova koji se protežu kroz rukopise te razdoblje nastanka rukopisa, može se zaključiti da je za navedene rukopise bio korišten isti papir te da se druge vrste papira nisu umetale.

Analiza je pokazala i to da u rukopisima Žman_74.6, Žman_74.9, Žman_74.16 i Žman_74.18 ne postoje vodeni znakovi koji se preklapaju. Primjerice u rukopisu 74.16 postoji pet motiva vodenih znakova, no oni se ne preklapaju ni s jednim vodenim znakom iz drugih rukopisa. Budući da je navedeni rukopis nastao od 1670. do 1694. godine, što je svakako kasnije od prethodnih rukopisa, to upućuje na zaključak da se u Žmanu nije koristio isti papir na samom početku i pri samom kraju stoljeća.

Analiza vodenih znakova žmanskih rukopisa izrađena na temelju vizualizacije podataka iz baza podatka ukazala je samo na neke od obrazaca nabave i korištenja papira u mjestu Žman. Dodatno, pokazana je korist takvih baza podataka, osobito kada je omogućena i integracija s katalozima rukopisa u kojima se vodeni znakovi nalaze. U daljnjim istraživanjima bit će zanimljivo istražiti načine i puteve nabave i obrasce korištenja papira na širem području kako bi se utvrdilo jesu li npr. susjedna mjesta koristila isti papir, jesu li župnici posuđivali papir međusobno, kako su ga i kada dodavali u svoje knjige i slične obrasce. Za takva je istraživanja 
potrebno prikupiti više podataka, a preduvjeti za njihovo prikupljanje ostvareni su izgradnjom baze vodenih znakova VoZnaZD. Detaljnija istraživanja vodenih znakova i identifikacija papirana te unos tih podataka u ovako pripremljenu bazu podataka značajno bi pridonio mogućnostima automatskog mapiranja trgovinskih i drugih veza između proizvođača i korisnika papira te razumijevanju pismenosti određenog područja. Daljnja bi istraživanja u tom slučaju trebala uključiti detaljnije kodikološke, paleografske, ali i druge analize.

\section{Zaključak}

Ovim su se radom nastojale prikazati mogućnosti filigranoloških istraživanja u kontekstu istraživanja pisane baštine, ali i svrnuti pozornost na važnost uporabe standardizirane baze podataka vodenih znakova koja bi se izrađivala na nacionalnoj razini i bila u otvorenom pristupu, što smatramo važnim preduvjetom za značajnija filigranološka istraživanja u Hrvatskoj, kao i za isporuku podataka o vodenim znakovima u međunarodne baze podataka vodenih znakova.

Kako bi se istražile mogućnosti filigranoloških istraživanja, u sklopu prikazanog projekta su na temelju pregleda literature iz područja filigranologije postavljeni teorijski temelji, a na temelju sadržajne analize relevantnih međunarodnih baza vodenih znakova izrađen je aplikacijski profil baze podataka vodenih znakova i protokol digitalizacije. Preduvjeti za filigranološka istraživanja ostvareni su izradom protokola digitalizacije vodenih znakova te baze podataka vodenih znakova VoZnaZD. Nakon digitalizacije i opisa vodenih znakova, kroz studiju slučaja istražene su mogućnosti filigranoloških istraživanja u kontekstu istraživanja pisane baštine.

Valja istaknuti da je značajniju analizu mogućnosti filigranoloških istraživanja potrebno učiniti na širem korpusu, za što je potrebna suradnja šire zajednice. Takvo je istraživanje u planu u idućim etapama projekta.

Nakon ovako provedenog istraživanja, kojim se ukazuje na mogućnosti i potencijal filigranoloških istraživanja te na povećanje istraživačkog potencijala baza vodenih znakova proporcionalno s povećanjem broja vodenih znakova uključenih u online dostupne baze, može se zaključiti da je potrebno čim prije izgraditi nacionalnu bazu vodenih znakova koja bi bila u otvorenom pristupu. To bi omogućilo značajnije filigranološke analize i bolje razumijevanje rukopisa i stare knjige te pisane kulture uopće.

Zaključno valja istaknuti da je istraživanje vodenih znakova u Hrvatskoj, iako započeto na izuzetno visokoj znanstvenoj razini, ostalo kao istraživačka grana pomalo zapostavljeno. Uz oživljavanje filigranoloških istraživanja, potrebno je izraditi i odgovarajuću bazu podataka koja će dati odgovore na mnoga kulturološki i povijesno važna pitanja vezana uz hrvatske kulturne, ekonomske, društvene i 
druge veze i okolnosti. Jednom izrađena, baza će moći biti nadopunjavana i novim elementima opisa u skladu s potrebama ustanova/korisnika i novim vodenim znakovima, što će pridonijeti kvalitetnijim bazama za istraživanje, ali i boljoj vidljivosti najranije vrijedne hrvatske pisane baštine u međunarodnoj zajednici. Baza VoZnaZD izgrađena je tako da omogućuje jednostavan unos podataka od strane svih onih ustanova koje digitaliziraju vodene znakove u svrhu stvaranja skupne nacionalne baze vodenih znakova te prema potrebama prošenje novim elementima opisa.

Ovim istraživanjem teorijski su potvrđene mogućnosti filigranoloških istraživanja, a istraživačke mogućnosti baze podataka istražene su kroz studiju slučaja, čime su nedvojbeno učinjeni temelji za praktičnu primjenu baze vodenih znakova i izradu nacionalnog skupnog kataloga vodenih znakova. Jasno se može utvrditi uloga filigranoloških istraživanja u utvrđivanju okolnosti i konteksta proizvodnje rukopisa, utvrđivanja trgovinskih i kulturnih veza među proizvođačima rukopisa, datiranju nedatiranih rukopisa te potreba za integracijom baze vodenih znakova i rukopisa koja značajno pridonosi kontekstualizaciji podataka o rukopisima i onima o vodenim znakovima i istraživačkom potencijalu obiju baza.

\section{LITERATURA}

ArhivPRO d.o.o. [citirano: 2020-11-06]. Dostupno na: http://www.arhivpro.hr/

Balta, I. Pregled pomoćnih povijesnih znanosti. Osijek: Matica hrvatska: Grafika, 2000.

Bernstein: the memory of paper. [citirano: 2020-11-06]. Dostupno na: https://memoryofpaper.eu/BernsteinPortal/appl_start.disp

Bidwell, J. The study of paper as evidence, artefact, and commodity. [citirano 2020-2910]. Dostupno na: https://ilab.org/articles/study-paper-evidence-artefact-and-commodity.

BO - Briquet Online. [citirano 2020-23-08]. Dostupno na: http://briquet-online.at/

Briquet, C. M. Les filigranes: dictionnaire historique des marques du papier des leur apparition vers 1282 jusqu'en 1600. Paris: Picard u. a., 1907.

Briquet, C. M. Les Filigranes, dictionnaire historique des marques du papier dès leur apparition vers 1282 jusqu'en 1600 : a facsimile of the 1907 edition with supplementary material contributed by a number of scholars / edited by Allan Stevenson. Amsterdam: Paper publications Society, 1968.

Bull's head and mermaid: the history of paper and watermarks from the Middle Ages to the modern period / edited by Peter Ruckert, Sandra Hodeček, Emanuel Wenger. 
Stuttgart: Landesarchiv Baden Württemberg ; Vienna: Austrian Academy of Sciences, 2009. [citirano 2020-29-10]. Dostupno na: https://bernstein.oeaw.ac.at/twiki/ pub/Main/ProjectExhibitions/bernstein_2009_book_en.pdf

Despot, M. Pokušaji manufakture u građanskoj Hrvatskoj u 18. stoljeću. Zagreb: JAZU, 1962.

Eineder, G. The ancient paper-mills of the former Austro-Hungarian Empire and their watermarks. Hilversum: Paper Publications Society, 1960.

Fischer von Waldheim, G. Beschreibung einiger typographischen Seltenheiten nebst Beyträgen zur Erfindungsgeschichte der Buchdruckerkunst. Nürnberg: Lechner, 1804.

Frauenknecht, E.; C. Kämmerer; P. Rückert; M. Stieglecker. Watermark - terms: vocabulary for watermark description. [citirano: 2020-11-06]. Dostupno na: https://www. memoryofpaper.eu/products/watermark_terms_v11.1_en.pdf

Glagolab: portal i digitalni laboratorij za suradnička istraživanja i promicanje hrvatskoga glagoljaštva. [citirano: 2020-11-06]. Dostupno na: https://glagolab.unizd.hr/

Gulin, A.; A. Kolarić; Z. Ladić. Voditelji i ravnatelji Odsjeka za povijesne znanosti Zavoda za povijesne i društvene znanosti Hrvatske akademije znanosti i umjetnosti u Zagrebu (1948.-1998.). // Zbornik Odsjeka za povijesne i društvene znanosti Hrvatske akademije znanosti i umjetnosti, 17(1999), 219-234. [citirano: 2020-11-06]. Dostupno na: https://hrcak.srce.hr/15870

Indigo: hybrid repository platform based on semantic technologies. [citirano: 2020-1106]. Dostupno na: http://www.eindigo.net/

Kero, P. Popis glagoljskih kodeksa Zadarske nadbiskupije. 2. izd. Zadar: Stalna izložba crkvene umjetnosti, Sveučilište u Zadru, 2015.

Labarre, E. J. Dictionary and encyclopaedia of paper and paper-making. London: Oxford University Press, 1952.

Lewincamp, S. Watermarks within the Middle Eastern manuscript collection of the Baillieu Library. // The Australian Library Journal 61, 2(2012), 95-104. DOI: https://doi. org/10.1080/00049670.2012.10722324.

Mošin, V. Filigranologija kao pomoćna historijska nauka // Zbornik odsjeka za povijesne znanosti Zavoda za povijesne i društvene znanosti Hrvatske akademije znanosti i umjetnosti, 1(1954), 25-93.

Mošin, V. Filigranološka problematika i papir Dubrovačkog arhiva. // Historijski zbornik 29-30 (1976-1977), 51-59.

Mošin, V. A.; S. M. Traljić. Vodeni znakovi XIII. i XVI. vijeka. Zagreb: Jugoslavenska akademija znanosti i umjetnosti, 1957.

Pantelić, M. Glagoljski kodeksi Bartola Krbavca. // Hrvatsko glagoljsko srednjovjekovlje / Marija Agnezija Pantelić; priredili Petar Bašić, Roman Turčinović. Zagreb: Kršćanska sadašnjost, 2013. Str. 145-246. 
Piccard, G. Die Wasserzeichenkartei Piccard im Hauptstaatsarchiv Stuttgart. Stuttgart: W. Kohlhammer, 1961-1997.

Piccard online. [citirano 2020-29-10]. Dostupno na: https://www.piccard-online.de/ start.php

Portal Pisana baština. [citirano: 2020-11-06]. Dostupno na: https://pisanabastina.unizd.hr/

Portal Pisana baština. Katalog rukopisa. [citirano: 2020-11-06]. Dostupno na: https:// pisanabastina.unizd.hr/?kr=1\&view $=$ grid\&page $=1$

Portal Pisana baština. Katalog vodenih znakova. [citirano: 2020-11-06]. Dostupno na: https://pisanabastina.unizd.hr/?kvz=l\&view=grid\&page $=1$

Puškadija-Ribkin, T. Vodeni znakovi papirane zagrebačkoga Stolnog kaptola. // Arhivski vjesnik 37(1994), 209-220.

Renhart, E.; M. Tomić. Digitalizacija, bibliografska obrada, istraživanje i komuniciranje zadarske pisane baštine. // Arhivi, knjižnice, muzeji: mogućnosti suradnje u okruženju globalne informacijske infrastrukture 20(2017), 222-267.

Renhart, E.; M. Tomić. Principles of work and guidelines. Version 3.0. [citirano: 202007-12]. Dostupno na: https://pisanabastina.unizd.hr/?pr=i\&id=12682.

Stipišić, J. Pomoćne povijesne znanosti u teoriji i praksi: latinska paleografija, opća diplomatika, kronologija. Zagreb: Školska knjiga, 1972.

Štefanac, T. Metode i postupci istraživanja i obrade vodenih znakova na građi iz fonda Nacionalne i sveučilišne knjižnice u Zagrebu. // Arhivi, knjižnice, muzeji: mogućnosti suradnje u okruženju globalne informacijske infrastrukture 23(2020). (u tisku)

Tomić, M. Katalogizacija starih rukopisa uporabom Pravilnika za opis i pristup građi u arhivima, knjižnicama i muzejima na primjeru zbirke glagoljskih kodeksa zadarske nadbiskupije. // Arhivi, knjižnice, muzeji: mogućnosti suradnje u okruženju globalne informacijske infrastrukture 21(2018), 189-231.

Tomić, M.; M. Willer. Glagoljski rukopisi kao privez i umjetna zbirka: primjena Pravilnika za opis i pristup građi u knjižnicama, arhivima i muzejima. // Arhivi, knjižnice, muzeji: mogućnosti suradnje u okruženju globalne informacijske infrastrukture, 23 (2020). (u tisku) 


\section{Prilog 1. Aplikacijski profil za opis vodenih znakova korišten u bazi vodenih znakova VoZnaZD}

\begin{tabular}{|c|c|}
\hline Naziv vodenog znaka & Naziv vodenog znaka dodjeljuje katalogizator. \\
\hline Motiv(i) vodenog znaka & $\begin{array}{l}\text { Nazivi motiva preuzimaju se iz kontroliranog } \\
\text { rječnika. }\end{array}$ \\
\hline Opis motiva vodenog znaka & $\begin{array}{l}\text { Dodatne nestrukturirane informacije o vodenom } \\
\text { znaku (npr. podatak o poziciji određenog dijela } \\
\text { vodenog znaka, broju motiva i ostalim značajkama } \\
\text { vodenog znaka koje katalogizator smatra važnim). }\end{array}$ \\
\hline \multicolumn{2}{|l|}{ Udaljenost okomitih linija } \\
\hline \multicolumn{2}{|l|}{ Gustoća vodoravnih linija } \\
\hline \multicolumn{2}{|l|}{ Širina i visina vodenog znaka } \\
\hline Briquetov broj & $\begin{array}{l}\text { Identifikacijski broj vodenog znaka iz Briquetova } \\
\text { kataloga Les Filigranes }\end{array}$ \\
\hline Papirana & $\begin{array}{l}\text { Naziv papirane (ako se može utvrditi). Naziv se } \\
\text { unosi u autoriziranom obliku. }\end{array}$ \\
\hline Proizvođač papira & $\begin{array}{l}\text { Ime proizvođača (ako se može utvrditi). Ime se } \\
\text { unosi u autoriziranom obliku. }\end{array}$ \\
\hline \multicolumn{2}{|c|}{ Elementi koji se odnose na kodeks u kojem je vodeni znak sadržan } \\
\hline Naslov & Naslov kodeksa u kojem je sadržan vodeni znak. \\
\hline Godina / Raspon godina & $\begin{array}{l}\text { Godina ili raspon godina proizvodnje kodeksa u } \\
\text { kojem je sadržan vodeni znak. }\end{array}$ \\
\hline Mjesto proizvodnje & $\begin{array}{l}\text { Mjesto proizvodnje kodeksa u kojem je sadržan } \\
\text { vodeni znak. Naziv se unosi u autoriziranom obliku. }\end{array}$ \\
\hline Ustanova & $\begin{array}{l}\text { Naziv ustanove u kojoj je pohranjen kodeks u ko- } \\
\text { jem je sadržan vodeni znak. }\end{array}$ \\
\hline Signatura kodeksa & Signatura kodeksa u kojem je sadržan vodeni znak. \\
\hline $\begin{array}{l}\text { Ustanova/projekt } \\
\text { digitalizacije }\end{array}$ & $\begin{array}{l}\text { Naziv ustanove/projekta u sklopu kojeg je digitali- } \\
\text { ziran vodeni znak. }\end{array}$ \\
\hline Napomena & $\begin{array}{l}\text { Dodatne informacije koje su značajne za kodeks, a } \\
\text { nisu sadržane u ostalim elementima opisa. }\end{array}$ \\
\hline
\end{tabular}

54 Broj se pronalazi u bazi podataka BO - Briquet Online, Bernstein - The Memory of Paper ili nekoj drugoj bazi vodenih znakova u kojoj se navodi Briquetov broj. 